\title{
Retheorizing the Presumption Against Implied Repeals
}

\author{
Karen Petroski†
}

TABLE OF CONTENTS

Introduction.

I. Background Concepts: Intentionalism, Formalism, and Updating

A. Intentionalism

B. Legislative Supremacy, Formalism, and Canons of Statutory Interpretation

C. Statutory Updating

II. The Presumption in Practice.

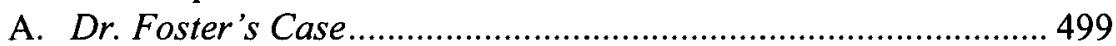

B. Nineteenth-Century Approaches and Elaborations.......................501

C. 1900-1985: The Persistence of Formalism ................................506

D. The Supreme Court's Use of the Presumption Since the 1980s: The Emergence of an Inflexible Rule

III. Other Conflict-Resolution Doctrines................................................. 518

A. Preemption Doctrine .......................................................... 518

B. Heightencd Stare Decisis for Statutory Precedents .................... 521

IV. Retheorizing the Presumption Against Implied Repeals................... 524

A. Alternative Rationales for the Presumption ................................524

B. The Shape of a New Presumption...........................................526

C. Applying the New Presumption...............................................529

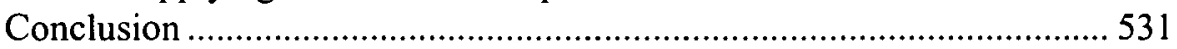

Appendix: Supreme Court Cases Addressing Implied Repeals,

1809-2003.

Copyright 102004 Califomia Law Review, Inc. California Law Review, Inc. (CLR) is a Califomia nonprofit corporation. CLR and the authors are solely responsible for the content of their publications.

$\dagger$ J.D. Candidate, School of Law, University of Califomia, Berkeley (Boalt Hall), 2004, I would like to thank Professor Philip Frickey for his suggestion of this topic and his invaluable support and guidance through the writing of this Comment. I would also like to thank the members of the California Law Review, cspecially Jean Galbraith, Kristi Hughes, Donna Maeda, David Steiner, Emily Zarins, and Jeana Zelan, for their help in improving this Comment. Any errors are mine alone. 


\title{
Retheorizing the Presumption Against Implied Repeals
}

\author{
Karen Petroski
}

\section{INTRODUCTION}

What should a court do when it is presented with two statutes that appear to be in conflict? If the conflict proves irreconcilable, and neither of the statutes is more specific than the other, a long-standing principle of statutory interpretation advises the court to conclude that the legislature's last word on the subject - the later-enacted statute-controls. The laterenacted statute therefore "repeals" by necessary implication the earlier, contrary statute to the extent of the conflict. ${ }^{1}$ This rule of thumb reflects an understanding that, occasionally, updating of the statutory scheme is desirable, either because this updating was intended (if not acknowledged) by the legislature ${ }^{2}$ or because the legislature's most recent enactments are more likely aligned with the electorate's current political preferences than are earlier enactments to the contrary. ${ }^{3}$

Litigants may find it useful to argue that an implied repeal has occurred, and courts frequently take such arguments seriously. ${ }^{4}$ Often, however, these arguments fail in the face of another long-standing interpretive guideline, which advises courts to presume that such a repeal was not

1. If one of the statutes is more specific than the other, the statutes may be reconciled by construing the more specific statute as an exception to the more general statute, regardless of the temporal relationship between the statutes. The current leading statutory interpretation treatise recognizes both the specific-controls-the-general canon and the later-enacted-statute rule. NORMAN J. Singer, i A Statutes and Statutory Construction $\S 23: 9$, at 458, $\S 23: 15$, at 511-12 (6th ed. 2002); see also WiLliam N. EsKRidge, JR. ET AL., Legislation AND STATUTORY INTERPRETATION 274-75 (2000). This Comment focuses primarily on the problems posed by conflicting statutes of equal generality, that is, on situations in which reconciliation of the statutes, if possible, must occur in some manner other than by construing one statute as providing for an exception to the other.

2. See, e.g., SINGER, supra note $1, \S 23: 9$, at 461, 469; Bowen v. Lease, 5 Hill 221, 225, n.a (N.Y. Sup. Ct. 1843).

3. See, e.g., Guido Calabresi, A Common Law for the Age of Statutes 5-7 (1982); J.F. Burrows, Inconsistent Statutes, 3 OTAGO L. Rev. 601, 612 (1976).

4. In the last three terms that preceded the writing of this Comment, for instance, the Supreme Court addressed the question of implied repeal in at least five cases: Branch v. Smith, 538 U.S. 254 , 273-76 (2003); Cook County, lllinois v. United States ex rel. Chandler, 538 U.S. 119, 130-34 (2003); United States v. Vonn, 535 U.S. 55, 65 (2002); J.E.M. AG Supply, lnc. v. Pioneer Hi-Bred lnt'l., Inc., 534 U.S. 124, $141-44$ (2001); INS v. St. Cyr, 533 U.S. 289, 298-99 (2001). 
intended and to reconcile the statutes if at all possible. ${ }^{5}$ This guideline, the presumption against implied repeals, functions as an obstacle to application of the rule described above. ${ }^{6}$ The presumption against implied repeals, unlike the later-enacted-statute rule, embodies a poliey of hostility to the notion of statutory updating unless the legislature makes that updating explicit. In its strongest form, the presumption amounts to a sort of clearstatement rule-allowing for repeal only by express provision-that negates the very notion of an implied repeal. ${ }^{7}$

The incompatible policies on statutory updating reflected by these principles make it difficult to articulate a rationale that reconciles them, and no serious attempt has been made to do so. ${ }^{8}$ Theoretical neglect of this problem threatens unfortunate results. Particularly in recent decades, the absence of any principled understanding of the purposes served by the presumption against implied repeals seems to have led a majority of current Supreme Court justices to transform the presumption into a rule forbidding implied repeals. The fractured recent opinions in Branch $v$. Smith ${ }^{9}$ show

5. See ESKRIDGE, JR. ET AL., supra note 1, at 273-74; SINGER, supra note 1, \$23:10, at 484-85.

6. The relationship between the later-enacted-statute rule and the presumption against implied repeals is oppositional, but deseribing the two principles as independent, opposing interpretive forces oversimplifies their relationship slightly. The presumption ean only really be understood against the backdrop of the later-enacted-statute rule and its effects, since the later-enacted-statute rule is what causes implied repeals to occur when they do occur. Thus, whenever this Comment describes an implied repeal as having occurred or been found, the Comment is also saying that the later-ellactedstatute rule has been given effeet. Despite the foeus on the presumption suggested by the title of this Comment, the Comment presents an argument for understanding the later-enacted-statute rule and its results, implied repeals, as natural parts of a statutory scheme. In the service of this goal, the Comment describes the current presumption against implied repeals (as used by the Supreme Court in, for example, Branch v. Smith) as a distorted version of what it really should be, and advances a new conception of the presumption as a properly cautionary refinement on or corollary to the later-enactedstatute rule.

7. See SINGER, supra note $1, \S 23: 10$, at $484-85$ ("This is true even to the extent that a construetion is superimposed over legislative intent to repeal, where two acts can ... stand together and both be given consonant operation."). On clear-statement rules, see ESKRIDGE, JR. ET AL., supra note 1, at 355-61; William N. Eskridge, JR. et al., Cases and Materials on Legislation: Statutes and the Creation of Public Policy 889-902 (3d ed. 2001).

8. The presumption and the later-enacted-statute rule have rarely been the subject of extended critical analysis. Judge Richard Posner advanced a limited critique of the presumption in two opinions he wrote for the Seventh Circuit in the late 1980s. See Edwards v. United States, 814 F.2d 486, 488-89 (7th Cir. 1989); Friedrieh v. City of Chicago, 888 F.2d 511, 516 (7th Cir. 1989), vacated by 499 U.S. 933 (1991); see also Richard A. Posner, Statutory Interpretation-In the Classroom and in the Courtroom, 50 U. CHI. L. REv. 800, 812-13 (1983) (arguing that none of the plausible rationales for the presumption against implied repeals is empirically supportable). Academic commentary on the presumption and on the subject of implied repeal has otherwise been limited primarily to description of the doctrines. See, e.g., David Robert Owen, Legislation-Interpretation and Construction-Prior Statute Not Repealed by Implication, Ex parte Sanford, 289 S.W. 2d 776 (Tex. Crim. App. 1956), 35 Tex. L. REv. 281 (1956); Recent Case, Statutes-Interpretation and Construction-Repeal by Implication, 10 Rutgers L. REv. 462 (1956); Note, Repeal by Implication, 55 Colum. L. REv. 1039 (1955); Note, Repeal or Amendment Implied from Later Inconsistent Enactment, 37 CoLUM. L. REv. 292 (1937).

9. 538 U.S. 254 (2003). 
how these justices' superficial semantic consensus masks fundamental disagreement about when statutory updating is appropriate. ${ }^{10}$ The Court's current categorical formulation of the presumption, which can be used to support diametrically opposed results, reduces the presumption to a rhetorical tool preventing candid judicial confrontation of serious questions about courts' role in interpreting statutes and about statutes' temporal dimensions. In this form, the presumption functions neither to guide judicial judgment to principled conclusions nor to send clear messages to the legislature about how best to draft its enactments to reach intended results.

After analyzing the contours of this problem, this Comment proposes a solution. Part I both introduces the vocabulary needed to analyze the issue and shows, from a theoretical perspective, why reexamination of the presumption is necessary. It first describes the debates over intentionalist and formalist approaches to statutory interpretation, suggesting some of the theoretical weaknesses of the traditional justifications for the presumption against implied repeals. Part I then addresses the question of statutory updating in more detail and attempts to remedy the previously inadequate conceptualization of the updating dilemmas courts face in cases involving conflicting statutes.

Part II describes how the current state of affairs came to be, showing from a practical perspective why reexamination of the presumption is necessary now. This Part traces the use of the presumption from its initial appearance in Anglo-American law in the seventeenth century through its use by the current Supreme Court. This history illustrates how the intentionalist and formalist assumptions underlying the presumption since its initial articulation have persisted through shifts in judicial approaches to statutory interpretation and through elaborations and expansions of the presumption. Part II concludes that the Court's current use of the presumption fails to further the policies underlying any previously offered rationale for the presumption.

As a preliminary step to retheorizing the presumption, Part III contextualizes it against the backdrop of two other approaches to the rcsolution of legal conflicts involving statutes: preemption doctrine and the arguments that have been advanced for heightened stare decisis value for statutoryinterpretation precedents. These doctrinal comparisons help to flesh out the issues that any new theorization of the presumption must address.

Part IV suggests a new approach to the presumption. This Part first critically reviews possible alternatives to the current rationales for the presumption and concludes that two institutional rationales support its continued, but altered, use. The Part then offers a set of recommendations for a more flexible, principled use of the presumption- one that allows courts to tailor their resolutions of statutory conflict to the nature of the statutes

10. See discussion of this case infra notes 130-46, 215-20 and accompanying text. 
involved and to the extent of reliance on the earlier statute. Finally, Part IV confirms the utility of these recommendations by exploring how they might be applied to the facts of two important Supreme Court cases involving inconsistent statutes.

\section{I}

\section{BACKGROUND CONCEPTS: INTENTIONALISM, FormaLISM, AND UPDATING}

\section{A. Intentionalism}

Traditional approaches to statutory interpretation, and traditional accounts of the rationale for the presumption against implied repeals, stress an interpreting court's role as the "honest agent" of the legislature, charged with the task of carrying out the legislature's original intent or purpose in enacting a statute." Under this view, when a court interprets a statute, its task is primarily "archaeological," a matter of mining the enacting legislature's intent or purpose from the text of the statute and possibly also from available extrinsic aids, such as legislative history. ${ }^{12}$ This Part presents some of the critiques of this view before assessing its utility in justifying the presumption against implied repeals.

Both traditional intentionalism, which seeks primarily to discern or reconstruct the meaning the enacting legislators understood to inhere in the statute they enacted, ${ }^{13}$ and purposivism, which involvcs determining the purpose for which the legislature enacted the law, ${ }^{14}$ are vulnerable to a variety of criticisms. Some critics have argued that the attribution of a single legislative intent or purpose to a statute is logically incoherent and empirically unsound. For example, even if the legislature's collective intent could be equated with the intent of a majority of the enacting legislators, the nature of the law-making process, which inevitably involves compromise and the cycling of preferences, means that legislative outcomes will not necessarily reflect the actual preferences of many individual Iegislators, much

11. See Eskridge, JR. ET Al., supra note 1, at 213-14; ReEd Dickerson, The Interpretation and Application of Statutes 67-102 (1975); William N. Eskridge, Jr. \& Philip P. Frickey, Statutory Interpretation as Practical Reasoning, 42 STAN. L. Rev. 321, 325-32 (1990); see also ANTONIN SCAlia, A Matter of Interpretation: Federal Courts and the Law 16-23 (1997) (critiquing intentionalism). Professor William Eskridge uses the term "honest agent" in this context. WILLIAM N. Eskridge, JR., Dynamic Statutory InTERPRetation 13 (1994) (quoting Frank H. Easterbrook, The Supreme Court, 1983 Term-Foreword: The Court and the Economic System, 98 HARv. L. Rev. 4, 60 (1984)).

12. The archaeological metaphor is used by T. Alexander Aleinikoff, Updating Statutory Interpretation, 87 MiCH. L. REv. 20, 22-32 (1988).

13. See Dickerson, supra note 11, at 67-86; Eskridge, Jr. \& Frickey, supra note 11, at 325-32; see also Church of the Holy Trinity v. United States, 143 U.S. 457, 459 (1892) ("lt is a familiar rule, that a thing may be within the letter of the statute and yet not within the statute, because not within its spirit, nor within the intention of its makers.").

14. See Henry M. Hart \& Albert M. Sacks, The Legal Process: Basic Problems in the MaKing and Application of LAW 1374-80 (1994); see also EsKridge, JR. ET AL., supra note 1, at 214 (identifying purposivism as a form of intentionalism); DiCKERSON, supra note 11 , at 87-102. 
less any unified legislative purpose. ${ }^{15}$ Other critics have noted that the use of legislative intent or purpose as the main source of legislative meaning may be inconsistent with other principles of statutory construction, such as the rule that the ordinary meaning of a statute's words should be the primary consideration in its interpretation. ${ }^{16}$ Most sweepingly, intentionalism has been criticized as an inaccurate description of what courts actually do when they interpret statutes. ${ }^{17}$

As is discussed more fully in Part II, the presumption against implied repeals has throughout its history been based primarily on an intentionalist rationale, and more specifically on particular assumptions regarding the type of intent that legislatures may have. The presumption proposes that legislatures neither (I) intend to create inconsistencies in the statutory scheme nor (2) intend their enactments to have unforeseen effects on other parts of the statutory scheme. ${ }^{18}$ These assumptions are vulnerable to the same criticisms leveled at intentionalism more generally. ${ }^{19}$ Moreover, the assumptions underlying the presumption against implied repeals may also be criticized for attributing a particular type of fixed and general intent or purpose to all legislative activity. Such an attribution is surely empirically indefensible. Although some have argued that it may be normatively desirable for courts to attribute empirically unsupportable metapurposes to legislative activity, ${ }^{20}$ critical attempts to defend the normative desirability of the particular intentionalist assumptions underlying the presumption against implied repeals have largely been cursory and indirect. ${ }^{21} \mathrm{~A}$ sound rationale for the presumption should address the justifications for such assumptions with greater care.

\section{B. Legislative Supremacy, Formalism, and Canons of Statutory Interpretation}

Despite the criticisms noted above, courts continue to appeal to broad intentionalist precepts in their opinions. ${ }^{22}$ The continued vitality of intentionalism is due partly to its grounding in principles of legislative supremacy. ${ }^{23}$ By asserting that their interpretations of statutes reflect

15. See EsKRIDGE, JR. ET AL., supra note 1, at 216-18; ESKRIDGE, JR., supra note 11, at 14; Eskridge, Jr. \& Frickey, supra note I1, at 326-27, 333.

16. See SCALla, supra note 11, at 16.

17. See Eskridge, Jr. \& Frickey, supra note 11, at 345-56; EsKRIDGE, JR., supra note 11, at 13; SCAL1A, supra note 11, at 21-22.

18. See, e.g., infra notes 66,69 (quoting nineteenth-eentury treatise writers' expressions of this approach).

19. See supra notes $15-17$ and accompanying text.

20. See, e.g., HART \& SACKs, supra note 14, at 1374-80

21. See, e.g., United States v. Hansen, 772 F.2d 940, 944 (D.C. Cir. 1985) (Scalia, J.); David L. Shapiro, Continuity and Change in Statutory Interpretation, 67 N.Y.U. L. REv. 921, 937 (1992).

22. See, e.g., Eskridge, Jr. \& Frickey, supra note 11, at 326.

23. See id. at $325-27,332-33$. 
legislative intent or purpose and thereby positioning themselves as the "honest agents" of legislatures, courts can deny any primary role as lawmakers and effectively rebut charges of countermajoritarianism. ${ }^{24}$ Despite some recent criticism of the need for a strong principle of legislative supremacy, ${ }^{25}$ the rationale remains powerful enough to ground even theories developed in reaction to intentionalism, such as Justice Scalia's textualism. ${ }^{26}$ This section focuses on onc set of judicial strategies for buttressing the principle of legislative supremacy: the formalist use of canons of statutory construction, which include the presumption against implied repeals. It concludes with a brief preview of the problems inherent in the Supreme Court's current use of the presumption for this purpose.

Judges have developed a number of interpretive practices to signal judicial restraint, the corollary of legislative supremacy, while actually engaging in judicial activism. Explicit appeals to intentionalist precepts are one such practice. A less direct approach involves the use of formalist techniques of interpretation. ${ }^{27}$ Formalism, in the statutory interpretation context, involves the application of unvarying rules, including canons of statutory construction, to decide interpretive questions. ${ }^{28}$ In invoking and applying such rules, courts assume a position of decisional passivity. Some judges self-consciously justify their formalism institutionally; these judges reason that consistent judicial use of relatively bright-line rules provides clear guidance to legislators regarding the likely treatment of their enactments by the judiciary, and that such consistency in interpretation will ultimately result in clearer legislative drafting. ${ }^{29}$

Despite the attractions of a formalist, rule-based approach to judicial decision making, in practice it is not incompatible with considerable judicial activism, as Professor Karl Llewellyn pointed out in his landmark 1950 article on appellate decision making. ${ }^{30}$ Writing from a legal realist

24. On the countermajoritarian difficulty, see Alexander M. Bickel, The Least Dangerous Branch: The Supreme Court at the Bar of Politics 16-23 (1962).

25. See William N. Eskridge, Jr., Spinning Legislative Supremacy, 78 Geo. L.J. 319, 320-22 (1989). Contra Daniel A. Farber, Statutory Interpretation and Legislative Supremacy, 78 GEO. L.J. 281, 292-93 (1989).

26. See John F. Manning, Textualism and the Equity of the Statute, 101 COLUM. L. REv. 1, 15-22 (2001).

27. Antonin Scalia, The Rule of Law as a Law of Rules, 56 U. CH1. L. REv. 1175, 1183-88 (1989); Chisom v. Roemer, 501 U.S. 380, 404 (199I) (Scalia, J., dissenting); see also United States v. Hansen, 772 F.2d 940, 944 (D.C. Cir. 1985) (Scalia, J.). Contra Daniel A. Farber, The Inevitability of Practical Reason: Statutes, Formalism, and the Rule of Law, 45 VAND. L. REv. 533, 543-47 (1992) (critiquing formalism).

28. See Chisom, 501 U.S. at 404 (Scalia, J., dissenting). Eskridge refers to this practice as "mechanical jurisprudence." William N. Eskridge, Jr., Dynamic Statutory Interpretation, I35 U. PA. L. REV. 1479, 1506-10 (1987).

29. See Hansen, 772 F.2d at 944.

30. Karl N. Llewellyn, Remarks on the Theory of Appellate Decision and the Rules or Canons About How Statutes Are To Be Construed, 3 VAND. L. REv. 395, 401 -06 (1950); see also Eskridge, Jr., 
perspective, Llewellyn suggested that the existing repertoire of canons was so diverse and internally conflicted as to provide a tool for nearly every conceivable desired judicial outcome. ${ }^{31}$ Although Llewellyn did not mention the presumption against implied repeals in his article, his argument regarding the canons' false promise of restraint and consistency of outcomes holds important lessons with respect to the presumption against implied repeals. ${ }^{32}$ In choosing whether to apply the later-enacted-statute rule or the presumption against implied repeals, courts must decide whether two putatively conflicting statutes are contrary to one another. Yet the canons themselves offer no guidance for determining when a relationship of contrariety exists between two statutes. Instead, courts determine the presence or absence of such a relationship through descriptive demonstration, usually either a reconciliation of the two statutes ${ }^{33}$ or an explanation of the reasons they cannot be reconciled. ${ }^{34}$ Such demonstrations are invariably specific to the potential statutory conflict in question and necessarily involve considerable interpretive and rhetorical creativity. ${ }^{35}$ Thus, like the

supra note 28, at 1506-10 (discussing critiques of "mechanical jurisprudence"); Shapiro, supra note 21, at $937-38,947 \& n .138$ (describing critiques of the canons).

31. In his article, Llewellyn provided a list of pairs of canons, each pair consisting of two rules that could be used to support two diametrically opposed outcomes. Llewellyn, supra note 30, at 401-06.

32. At least one contemporaneous commentator secmed to note this fact. See Recent Case, Statutes-Interpretation and Construction-Repeal by Implication, supra note 8, at 463 ("Such rules [as the canons] afford little help, since they invariably eome in pairs of opposites, e.g., 'Repeals by implication are not favored,'... and 'In case of irreconcilable confliet, the later enactment governs' ... The text [treatise] writers have done little more than restate these canon couplets.").

33. See, e.g., Dr. Foster's Case, 77 Eng. Rep. 1222, 1232 (K.B. 1614).

34. See, e.g., United States v. Jonas, 86 U.S. 598, 603 (1873).

35. Courts and commentators have attempted to limit the scope of this creativity with respect to the presumption against implied repeals by developing a host of related sub-rules. One of the longestlived of these sub-rules is the principle that a statute couched in negative words and addressing the same subject or conduct as an earlier statute couched in positive words will implicitly repeal that earlier statute. See Dr. Foster's Case, 77 Eng. Rep. at 1231. This sub-rule, like others related to the presumption, appears to limit the number of instances in which a court will attempt to reconcile two arguably conflicting statutes through creative interpretation.

However, the overall usefulness of such sub-rules as constraining forces on judicial creativity is limited. First, the sub-rules are not parts of a comprehensive scheme for determining when apparently conflicting statutes may or may not be reconciled. See, e.g., SINGER, supra note 1, §\$ 23:12-28, at 495555. By definition, instances of apparent contrariety not covered by the sub-rules remain open to interpretive creativity. Seeond, in general the sub-rules address only the easy cases, in partieular those involving verbal or logical contradiction. They tend not to provide guidanee in more difficult cases, where contrariety might or might not be present, depending on how a court decides to interpret "contrariety": Is it strictly logical contradiction? Disparity of purpose? Finally, some of the nules related to the presumption replicate the ambiguity inherent in the tension between the presumption against implied repeals and its companion, the later-enacted-statute rule. For instance, the rule that a general statute is not to be interpreted to abrogate a speeific statute comes with its own canonical partner, the principle that a later-enacted statute intended as a general, complete, and comprehensive revision of a particular field of law implicitly repeals whatever specific statutes previously constituted the law in that area. See infra Part II.B. The choice between these two maxims requires a judicial decision regarding the meaning of "general" or "comprehensive" that is not unlike the nature of the 
other canons of statutory construction debunked by Llewellyn, the presumption against implied repeals and its corollaries allow courts to exercise interpretive freedom while signaling interpretive restraint.

As Part II shows, the Supreme Court's use of the presumption against implied repeals has historically been quite formalistic and has become markedly more so in recent decades ${ }^{36}$ Recent use of the presumption as a strict rule barring implied repeal under any circumstances arguably allows the Court greater latitude to engage in "tortured judicial legislation" to reconcile putatively conflicting statutes without candidly weighing complex policy considerations. ${ }^{37}$ This arguable usurpation of the legislature's function bears out Llewellyn's insight that deferential formalist rhetoric may mask significant judicial assertiveness. Moreover, considerations of judicial candor aside, the Court's use of the presumption as a strict rule cannot be said to have resulted in the transmission of a consistent message to the legislature, because the Court does not invoke the canon consistently. ${ }^{38}$ These problems do not mean that the canon is indefensible as a tool for signaling and ensuring legislative supremacy and judicial deference. They do suggest, however, that if the canon is to serve these functions, it should be understood and applied in a manner that acknowledges and guards against these problems.

\section{Statutory Updating}

In addition to allowing courts to adopt a posture of interpretive passivity, many of the canons embody a related substantive preference for the status quo, an acknowledgment that in case of an evenly balanced conflict between the preexisting legal fabric and a statute threatening to alter it, the judiciary, as a fundamentally conservative institution, should choose not to alter the fabric. ${ }^{39}$ These canons, including the presumption against implied

deeision courts must make in determining the meaning of "contrary" in any given case of potential statutory conflict.

36. See Farber, supra note 27 , at 543-47 (discussing revival of formalism generally); see also infra Part II.D.

37. Branch v. Smith, 538 U.S. 254, 292 (2003) (Stevens, J., concurring) (describing the plurality's interpretive reconciliation of conflicting statutes as "tortured judicial legislation"); see also id. at 1455 (O'Connor, J., dissenting) (quoting with approval Justice Stevens's characterization of the plurality's interpretive reconciliation).

38. See, e.g., Argentine Republic v. Amerada Hess Shipping Corp., 488 U.S. 428 (1989), discussed infra notes 119-28 and accompanying text. In this case, the majority arguably concluded that an implied repeal had occurred but refused to use the term "implied repeal" to describe the result of its interpretation of the conflicting statutes at issue. $I d$. at 437-38. On the desirability of candor in judicial opinions, see William D. Popkin, The Dynamic Judicial Opinion, Issues in Legal Scholarship (2002): Article 7, at 8-I0, at http://www.bepress.com/ils/iss3/art7.

39. David Shapiro, for instance, argues that "the dominant theme running through most interpretive guides ... is that close questions of construction should be resolved in favor of continuity and against change." Shapiro, supra note 21 , at 925 . He maintains that courts should self-consciously adhere to these principles in order to preserve their institutional legitimacy and to capitalize on their institutional competency as the most conservative branch of government. Id. at 949-50. 
repeals, express a preference for vertical coherence, or consistency of the statutory scheme over time, possibly at the expense of horizontal coherence, or consistency of the statutory scheme at any given time. ${ }^{40}$ In other words, they reflect a position of hostility toward statutory updating. This section looks more carefully at the mechanisms by which statutory updating occurs and at the updating dilemmas in which conflicting statutes place courts.

In theory, updating of the statutory scheme may be accomplished through legislative or judicial action. Legislatures can update the statutory scheme by amending and repealing old statutes as well as by enacting new ones with explicit or implicit effects on existing statutes. Indeed, the notion that legislatures must leave their successor legislatures free to update the statutory scheme has the status of a constitutional principle. ${ }^{41}$ This rule against legislative entrenchment reflects an acknowledgment that legislative updating is desirable and necessary. ${ }^{42}$

The legislative process can frustrate the legislature's exercise of this updating power. ${ }^{43}$ But courts can also update the statutory scheme. They can openly or covertly interpret statutes in a nonoriginalist manner. ${ }^{44}$ They can interpret statutes to conform to judicially updated constitutional doctrine $^{45}$ or update statutory law by revisiting and rejecting their own previous interpretations of statutes. ${ }^{46}$ Courts may wish to do all of these

40. On shifts in historical emphasis on vertical and horizontal coherence, see ESKRIDGE, JR. ET AL., supra note 7, at 599-600. Other canons, such as the rule that statutes should be read in pari materia and possibly also the later-enacted-statute rule, seem to express a preference for horizontal coherence.

41. See Eric A. Posner \& Adrian Vermeule, Legislative Entrenchment: A Reappraisal, 111 YALE L.J. 1665, 1665-66 (2002) (explaining and offering a critique of the principle); Julian N. Eule, Temporal Limits on the Legislative Mandate: Entrenchment and Retroactivity, 1987 AM. B. FounD. RES. J. 379, 384-427; see also Burrows, supra note 3, at 612.

42. See CALABRESI, supra note 3, at 1-7; Eule, supra note 41, at 404-05.

43. See, e.g., CALABRESI, supra note 3, at 6; see also discussion supra note 15 and accompanying text.

44. See id, at 31-43; see also EsKRIDGE, JR., supra note 11, at 48 (arguing that in practice "statutory interpretation is ... responsive to the current as well as the historical political culture").

45. See Aleinikoff, supra note 12, at 39; CALABRESI, supra note 3, at 16-17. The canon of avoiding constitutional questions represents a mechanism for preventing unnecessary instanccs of such constitutional updating. See, e.g., Ex parte Randolph, 20 F. Cas. 242, 254 (C.C.D. Va. 1833) (No. 11,558); Crowell v. Benson, 285 U.S. 22, 62 (1932) ("When the validity of an act of the Congress is drawn in question, and even if a serious doubt of constitutionality is raised, it is a cardinal principle that this Court will first ascertain whether a eonstruction of the statute is fairly possible by which the question may be avoided."); see also Ashwander v. Tenn. Valley Auth., 297 U.S. 288, 346-49 (1936) (Brandeis, J, concurring). Despite its overt resistance to constitutional updating, however, the avoidance canon allows courts to legitimate legislative updating of the legal scheme; it also makes courts the agents of statutory updating. Because courts invoking the canon examine current constitutional doctrine in interpreting potentially unconstitutional statutes, the canon "exert[s] an updating influence on the intcrpretation of statutes" as well as on the Constitution. Aleinikoff, supra note 12 , at 39 .

46. See infra Part III.B 
things in part precisely because the legislature is perceived to have been frustrated in its updating efforts. ${ }^{47}$

To the extent that judicial updating of the statutory scheme conflicts with the principle of legislative supremacy, it is deeply inconsistent with what courts often claim to be doing when they interpret and apply statutes. ${ }^{48}$ The presumption against implied repeals, which appears to reflect hostility to both judicial and legislative updating, suffers from a similar inconsistency. Courts applying the presumption continue to give effect to older statutes and thus assert that they are refraining from judicial updating. But use of the presumption can also frustrate legislative attempts to update the statutory scheme by compelling strained interpretations of newer statutes in order to reconcile them with older ones. ${ }^{49}$ In this way, some antiupdating effects of the presumption conflict with its justification as a tool for ensuring legislative supremacy. Moreover, in practice, the presumption does not always prevent judicial updating. In the mid-1980s, then Judge Scalia noted that the practice of accommodating two apparently conflicting statutes can cause changes in the meanings attributed to them: "The earlier statute will be given one interpretation at the time it is first passed, but a different interpretation later, when there is a need to narrow it in order to 'make room' for the operative effect of the later enactment." 50 Thus, despite the presumption's basis in the principle that the task of updating the statutory scheme belongs to the legislature, its use may allow courts to take on that task themselves. ${ }^{51}$ The more strongly the presumption is applied as a rule barring a conclusion of implied repeal, the more profound this

47. See CaLABRESI, supra note 3, at 1-7.

48. For this reason, some eritics have encouraged courts to avoid judicial updating. See Shapiro, supra note 21, at 925-26 (advocating heightened judicial self-consciousness of courts' "essentially conservative role"); SCALIA, supra note 11, at 14-37. Other commentators, however, have suggested that judicial updating is less problematic, both because the principle of legislative supremacy is in practice an unattainable ideal-and not even necessarily a desirable one-and because statutory updating is necessary, however it may be achieved. See Eskridge, Jr., supra note 25, at 322, 324; CALABRESI, supra note 3, at 5-7.

49. See, e.g., Branch v. Smith, 538 U.S. 254, 298 (2003) (O'Connor, J., dissenting)

50. Address by Judge Antonin Scalia, Speech on Use of Legislative History 7 (delivered between fall 1985 and spring 1986 at various law schools), quoted in Aleinikoff, supra note 12 , at 38 . Under this view, although the avowed purpose of the presumption is to promote vertical coherence of the statutory scheme across time, in practice it instead promotes horizontal coherence at the expensc of continuity. For examples of this use of the presumption in practice, see infra Part lll.D.

51. Elmer Dreidger, author of a Canadian treatise on statutory interpretation, has suggested that the term "implied repeal" is a misnomer, bccause a judicial interpretation of a latcr statute as inconsistent with an earlier one is not a legislative act, but merely a conclusion that "a later statute erects an obstacle to... [the] operation of the earlier statute, and when the obstacle is removed the original statute again operates according to its terms." Elmer A. DRIEdGer, Construction of STATuTEs 233 (2d ed. 1983). This insight is not incompatible with the position taken in this Comment that courts may in practice update the statutory scheme in one way, through acts of interpretation, while claiming that the updating task is the exclusive job of the legislaturc, to be exercised through acts of express enactment and repeal. 
tension between asserted legislative supremacy and actual interpretive creativity becomes.

A different kind of inconsistency exists between the presumption against implied repeals and its companion, the later-enacted-statute rule. In theory, in a situation of potential implied repeal, a court keeps the presumption in mind while considering whether the statutes in question are so irreconcilable that the later-enacted-statute rule applies. This practice, however, forces a court simultaneously to embrace conflicting assumptions regarding the desirability of statutory updating and the nature of legislative agency over time.

As traditionally formulated and applied, the presumption requires a properly deferential court to effectuate as many extant expressions of legislative will as possible. This use of the presumption seems to reflect a view of the legislature as a body unified across time, whose will, once expressed, should always be supreme. ${ }^{52}$ In contrast, the later-enacted-statute rule, which requires a court to conclude that recent expressions of legislative will displace what the court perceives as incompatible earlier expressions of legislative will, seems to require the court to regard more recent legislatures as distinct entities from earlier ones. ${ }^{53}$ In other words, the laterenacted-statute rule reflects an understanding of legislative agency and will as contingent on and defined by the shifting nature of the electorate that exercises its will through successive legislatures, rather than as an atemporal, unified institutional expression of will. The presumption, in contrast, seems to regard legislative will not as the articulation of constituencies' wills, but as an institutional expression of will. ${ }^{54}$

52. See infra note 69.

53. Otherwise, any judicial conclusion that an earlier statute is no longer effective, absent express legislative instruction to that effect, constitutes a straightforward substitution of judicial will for legislative will, rather than a deferential judicial articulation and effectuation of legislative will. See The Federalist No. 78, at 398 (Alexander Hamilton) (E.P. Dutton 1937). On the practice of viewing successive legislatures as distinct majoritarian entities, see, for example, Eule, supra note 41, at 394 405 (describing the "temporal mandate" theory of legislative agency). See also Robert Bennett, Justifying Dynamism, Issues IN LEGAL SchOlaRShIP (2002): Article 4, at 7-9, at http://www.bepress.com/ils/iss $3 /$ art4 (arguing that interpreting courts should regard as supreme the will of the sitting legislature rather than that of the enacting legislature); Bernard Bell, Hypnotized by Images of the Past: Dynamic Interpretation and the Flawed Majoritarianism of Statutory Law, ISSUES IN LEgal SchOlaRshiP (2002): Article 12, at 16-21, at http://www.bepress.com/ils/iss3/art12 (arguing that the longevity of statutes renders them antimajoritarian).

54. A similar dilemma exists if the presumption and the later-enacted-statute rule are justified not on intentionalist grounds but on formalist grounds. A textualist applying the presumption to reconcile conflicting statutes does so in the service of what Professor William Buzbee has called "the oneCongress fiction." William W. Buzbee, The One-Congress Fiction in Statutory Interpretation, I49 U. PA. L. REv. 171 (2000). This is the assumption that statutes should be treated as an atemporal "single document written by an ideal drafter who integrates them into a super-text." Id. at 174 (quoting William D. Popkin, An "Internal" Critique of Justice Scalia's Theory of Statutory Interpretation, 76 MINN. L. REv. 1133, 1148 (1992)). Buzbee argues that this fiction allows those interpreting statutes to engage in "unpredictable and unprincipled ends-oriented interpretation." Id. at 176. A court applying the later-enacted-statute rule abandons the atemporal "ideal drafter" notion by assuming that the 
Accordingly, application of the presumption against implied repeals can involve courts in two types of inconsistency, which are themselves in tension. Courts applying the presumption in its strongest form claim to be preserving the existing statutory fabric at all costs, when in fact their interpretations of the statutory fabric inevitably disturb it. On the other hand, a court applying the presumption forthrightly as a presumption, rather than as an ironciad rule, must also consider whether or not the later-enactedstatute rule applies, and this requires the court to entertain inconsistent conceptions of legislative will and the desirability of statutory updating. Few other legal problems so baldly force the same kind of choice between incompatible understandings of the functions of courts and legislatures. ${ }^{55}$ The relative lack of any doctrinal tools for making this choice may provide one explanation for the two main developments described in the following Part: the comparative undertheorization of the presumption over its long history and the Supreme Court's recent turn toward application of the presumption as an absolute rule.

\section{II}

\section{The Presumption in Practice}

A principle recognizable as the presumption against implied repeals seems to have been articulated for the first time in seventeenth-century England. Despite significant subsequent shifts in the nature of the legislative process and in courts' self-awareness about their relationship to this process, the rationales advanced for the presumption have remained remarkably consistent since the principle's first appearance. Courts do not, however, appear to have applied the presumption in a comparably consistent way over this long period. This Part describes this disjunction in some detail, surveying the history of the justifications for and uses of the presumption. The narrative presented explains how retheorization of the presumption has come to be necessary now.

\section{A. Dr. Foster's Case}

Sir Edward Coke's 1614 report on Dr. Foster's Case is the earliest case cited in treatises on statutory interpretation as foundational authority for the presumption against implied repeals. ${ }^{56}$ In this case, Coke considers

\footnotetext{
historical sequencc of enactmcnts is part of their meaning. Buzbce presents a similar approach as an alternative to the one-Congress fiction. Id. at 245-49.

55. Exceptions may be the questions of statutory entrenchment and retroactivity. See generally Eule, supra note 41 .

56. 77 Eng. Rep. 1222 (K.B. 1614). The case was cited wcll into the ninetecnth century in both British and American treatises on statutory interpretation. See, e.g., THEODORE SEDGWICK, A TrEatisE on the Rules Which Govern the Interpretation and application of Statutory and Constitutional Law 126-27 (New York, John S. Voorhies 1857); Sir Peter Benson Maxwell,
} 
the relationships between several Elizabethan and Jacobean statutes providing for different punishments for those accused and convicted as recusants. ${ }^{57}$ In his analysis, Coke first acknowledges the later-enacted-statute rule, leges posteriores priores contrarias abrogant. ${ }^{58}$ Coke next focuses on the meaning of "contrary" and in so doing analyzes, and implicitly limits, the ways in which laws may be contrary to one another. ${ }^{59}$ Despite the formalist implications of this analysis, Coke also suggests that contrariety is at least in part a product of interpretation by directing judges to defer to the "wisdom" of legislatures and to refrain from manufacturing this kind of relationship between statutes:

[I]t must be known, that forasmuch as Acts of Parliaments are established with such gravity, wisdom, and universal consent of the whole realm, for the advancement of the commonwealth, they ought not by any constrained construction out of the general and ambiguous words of a subsequent Act, to be abrogated [but] ... ought to be maintained and supported with a benign and favourable construction. ${ }^{60}$

Significantly, Coke does not acknowledge that "constrained construction" may be also necessary to keep two conflicting statutes in effect. Indeed, when used to avoid an implied repeal, construction becomes by Coke's definition not "constrained" but "benign and favourable." Coke thus suggests that particular acts of interpretation take on a desirable or undesirable character largely on the basis of the results they yield. This approach in turn suggests a presumption of considerable strength.

ON THE INTERPRETATION OF STATUTES 134 (London, William Maxwell \& Son 1875) (discussed infra Part II.B).

57. 1 Eliz.; 23 Eliz.; 28 Eliz.; 35 Eliz.; 7 Jac., cap. 6.

58. “Later laws abrogate contrary earlier ones." Dr. Foster's Case, 77 Eng. Rep. at 1231. For the Roman law versions of this rule, see THE Digest of Justinian 13, 15 (Alan Watson ed., 1985). Coke is elsewhere willing to apply the later-enacted-statute rule and to find that an implied repeal has occurred without invoking the presumption against implied repeals. See SiR Edward CoKE, THE Second PaRt of the Institutes of the Laws of England: Containing the Exposition of Many AnCient and Other Statutes 686 (London, W. Clarke \& Sons 1809).

59. Coke notes that laws might be contrary "in quality"; in other words, one act could set forth a positive injunction and a later act set forth a negative one on the same subject. Dr. Foster's Case, 77 Eng. Rep. at 1231. Two laws might also be contrary "in matter," although both affirmative or negative. Id. at 1232. For example, one act could provide for the trial of a particular offense before a specialized court and a later act provide for the trial of the same offense before any common law court; the later act would override the earlier one.

On the relationship between the meaning of "contrary" and the meaning of "repugnant" (the word often used in later formulations of the presumption against implied repeals), see Caleb Nelson, Preemption, 86 VA. L. REv. 225, 236-37 (2000).

60. According to Coke, proper respect for the "wisdom" and "universal consent" embodied in enacted laws indicates that contrariety between laws is undesirable as a conclusion, even if it would in some cases be diseoverable through "eonstrained construction." Dr. Foster's Case, 77 Eng. Rep. at 1232.

61. Id. 
In keeping with his articulation of a rigid rule, Coke's overall point is one of interpretive restraint. ${ }^{62}$ At the same time, Coke acknowledges interpretive freedom. He implicitly concedes that courts are capable of calibrating the level of constraint or generosity in their constructions of statutes, notes that contrariety is "multiplex,"63 and does not discourage courts from using narrow constructions to avert conflict between statutes. Finally, he demonstrates the appropriate use of this interpretive freedom through skillful logical reconciliation of three different statutory conflicts. ${ }^{64}$

Coke's ambivalence regarding interpretive constraint and freedom anticipated later treatments of the subject. However, because of the immense differences between the institutional context within which Coke wrote and that of even the earliest American courts, an analysis of his concerns is inadequate to explain later approaches. ${ }^{65}$ The following discussion focuses instead on the surprisingly minimal transformation of Coke's approach and avowed concerns in later treatments of the doctrine of implied repeal. The fundamental congruence between Coke's approach and so many later approaches, notwithstanding major differences in institutional context, supports the conclusion that the presumption is ripe for reexamination.

\section{B. Nineteenth-Century Approaches and Elaborations}

American courts and commentators initially imported the presumption against implied repeals into American law directly from Coke with little basic alteration. ${ }^{66}$ Although the nineteenth century saw some significant

62. Id.

63. Id. at 1231 .

64. One of the acts Coke examined provided for assessment of fines for every Sunday and holiday a recusant failed to attend services, 23 Eliz., while an earlier act had provided for assessment of fines by the month, 1 Eliz. These acts were not contrary, notes Coke, because the fines were assessed differently and, once collected, went to different accounts. 77 Eng. Rep. at 1232. The acts could be distinguished as not imposing mutually contradictory obligations on those subject to their terms and thus were not contrary to one another. Another pair of statutes involved an act that gave the power to indict for recusancy to an array of officials, 23 Eliz., and a later act that restricted the forum for recusancy convictions, 28 Eliz. These were not contrary because the meaning of the earlier act could be restricted to a conferral of the power to indict on certain persons. 77 Eng. Rep. at 1232. A third set of potentially conflicting acts provided for different agents of punishment of a feme covert convicted of recusancy. 23 Eliz.; 35 Eliz.; 7 Jac., cap. 6 . Here, Coke reasons, the Crown could choose which statute to use to punish the convict. 77 Eng. Rep. at 1232-33. Like the first pair of statutes, these did not produce conflicting obligations, but redundant punishments. Formally and logically, they were not in conflict.

65. See William D. Popkin, Statutes in Court: The History and Theory of Statutory INTERPRETATION 11-19 (1999) (discussing the permeable institutional boundary between courts and Parliament in sixteenth- and seventeenth-century England); Manning, supra note 26, at 56-85 (analyzing institutional differences between courts in early modern England and in the early American republic in context of theories of statutory interpretation).

66. In an 1857 treatise, Theodore Sedgwick writes,

in this country, on the same principle [as Dr. Foster's Case], it has been said that laws are presumed to be passed with deliberation, and with full knowledge of all existing ones on the 
elaborations of the principle, these elaborations did not propose any radically new approaches to the problem of statutory conflict in the American context or update it for a self-consciously developing polity. Instead, American courts and commentators generally proceeded from the same assumptions set forth in Dr. Foster's Case and followed Coke's lead in using and advocating interpretive techniques that were in tension with these assumptions.

Some early nineteenth-century treatises on statutory interpretation take Coke's reasoning in Dr. Foster's Case to its logical conclusion. Such reasoning adds the more specific assumption that laws are passed with "deliberation, and with full knowledge of all existing ones on the same subject"67 to Coke's assumption of the "gravity, wisdom, and universal consent" ${ }^{\prime \prime 68}$ inherent in statutory enactments and underlying the presumption against implied repeals. This approach strengthens Coke's assumptions by advancing a view of the legislature as not only omniscient, but possessing a unitary consciousness. ${ }^{69}$ Like Coke, these treatise writers advocated use of a particularly strong version of the presumption against implied repeals. ${ }^{70}$

Most nineteenth-century treatise writers, however, advised a more careful reading of the implications of Coke's words in Dr. Foster's Case. These writers warned against reification of the presumption against implied repeals and reminded their readers that it was originally articulated as a

same subject; and it is, therefore, but reasonable to conclude that the legislature, in passing a statute, did not intend to interfere with or abrogate any prior law relating to the matter, unless the repugnancy between the two is irreconcilable; and hence, a repeal by implication is not favored; on the contrary, courts are bound to uphold the prior law, if the two acts may well subsist together.

SEDGwiCK, supra note 56, at 126-27. Two decades later, annotating Sir Fortunatus Dwarris's 1830 British treatise on statutory construction for American readers, Platt Potter noted that "[ $t$ ]he American authorities are substantially to the same effect [as Dr. Foster's Case]." Fortunatus Dwarris, A General Treatise on Statutes: Their Rules of Construction, and the Proper Boundaries of Legislation and of Judicial Interpretation (I830), with Platt Potter, american Notes and AdDitions, and with Notes and Maxims of Constitutional and of statute Construction 154 n.4 (Albany, N.Y., W. Gould \& Sons 1875).

67. SEDGwICK, supra note 56, at 127. Sedgwick drew this formulation from Bowen $v$. Lease, 5 Hill 221, 225 n.a (N.Y. Sup. Ct. 1843).

68. Dr. Foster's Case, 77 Eng. Rep. at 1232.

69. Some formulations explicitly described this unitary will as persisting through time. In a contemporary British treatise, Sir Peter Benson Maxwell takes Sedgwick's imputation of omniscience to the legislature one step further:

An author must be supposed to be consistent with himself; and, therefore, if in one place he has expressed his mind clearly, it ought to be presumed that he is still of the same mind in another place.... In this respect, the work of the Legislature must be treated in the same manner as that of any other author... To impute repugnancy, is to impute ignorance, or carelessness of expression, or confusion of thought; and not only, therefore, is repeal by implication not favoured, but any construction involving it is to be rejected in favour of any other which the language will rationally bear.

MAXWELL, supra note 56, at I33.

70. Id. at 133-34. 
presumption, not a prescription. ${ }^{71}$ On balance, the treatises suggest that, toward the end of the nineteenth century, courts were increasingly willing to weigh "convenience" against the presumption when deciding what to do with arguably conflicting statutes. ${ }^{72}$ In this respect, the treatises appear to present an accurate reflection of the nineteenth-century Supreme Court's actual use of implied repeals doctrine. Between 1800 and 1849, the Court considered the possibility of an implied repeal in fifteen majority opinions, but found that an implied repeal had occurred in only one of these cases. ${ }^{73}$ Between 1850 and 1899, however, the Court considered the question much more frequently and found that implied repeals had occurred more frequently as well: the Court argued, mentioned, or concluded that implied repeals had occurred in thirty-six of ninety-nine cases in which it considered the question. ${ }^{74}$ Some opinions, in fact, apply the later-enacted-statute rule without mentioning the presumption against implied repeals. ${ }^{75}$

The Court's apparent movement away from a strict "no repeal by implication" rule was assisted by the judicial development, in the second half of the nineteenth century, of an additional basis for finding that repeal

71. Potter, for example, noted in 1874 that

[t] he leaning of the courts is so strong against repealing the positive provisions of a former statute by construction, as almost to establish the doctrine of "no repeal by implication." But this goes beyond the limits of Foster's case, that "such repeal is not to be favored;" and, in a reeent case, Lord Denman said, "while we hold that a positive enactment is not to be restrained by inference, we must also act on the maxim, "leges posteriores priores contrarias abrogant,' whenever it comes into operation."

POTTER, supra note 66, at 154 .

72. In the 1891 first edition of the statutory construetion treatise that remains the American authority on the subject, Jabez Gridley Sutherland noted,

In cases of doubt, repeal of a statute or of the common law may be deemed intended in favor of convenience. An argument based on inconvenience is forcible in law; no less so is one to avoid what is unjust or unreasonable. Like considerations of what is convenient, just or reasonable, when they can be invoked against the implication of repeal, will be still more potent.

Jabez Gridley Sutherland, Statutes and Statutory Construction 206 (Chicago, Callaghan \& Co. 1891).

73. For a description of the method used to collect these cases, and a list of the cases themselves, see the Appendix. Interestingly, the conflict at issue in the sole pre-1850 case to find an implied repeal involved not a situation of positive contrariety or repugnancy between two substantially different statutes, but an alteration in a reenacted statute. Soc'y for the Propagation of Gospel in Foreign Parts v. Town of Pawlet, 29 U.S. 480, 509 (1830) (finding that "the proviso in favour of lands granted to pious and charitable uses was silently dropped, and must be deemed to be repealed by implieation").

74. See Appendix.

75. For example, in an 1863 case arising under the Patent Acts of the 1830s, Justice Swayne wrote, "The new provision in the act of 1839 , is wholly independent of the act of 1836; by necessary implication it repeals the conflicting provision upon the same subject in the earlier aet." Godfrey $\mathrm{v}$. Eames, 68 U.S. 317,325 (1864). Some approaches to implied repeal during this period appeal at least in part to "convenience," even if they do not use that word. For example, in holding that an earlier act had been repealed by implication in an 1854 ease concerning customs statutes, Justice Campbell wrote, "[T]he importance of the [earlier act] ... had ceased, and ... the retention of it, as a cumulative penalty, would accomplish no good, and serve only to involve the government in litigation." United States v. Sixty-Seven Packages of Dry Goods, 58 U.S. 85, 96 (1854) (Campbell, J., dissenting). 
by implication had occurred. Coke and his more faithful successors applied the later-enacted-statute rule only in cases involving logical contrariety or repugnancy between two laws. ${ }^{76}$ In cases later in the nineteenth century, however, the Court began to recognize as implied repeals situations in which clear evidence of a later legislature's intent to effect a comprehensive revision of the law in a given area functioned to displace earlier isolated laws on the same subject. ${ }^{77}$ On its face, the appearance of this alternative rationale for a conclusion of implied repeal seems to reject Coke's approach by refusing to recognize logical contradiction as the only possible justification for a finding of implied repeal. The comprehensiverevision rationale also appears inherently more hospitable to the notion of legislative updating than the repugnance rationale. Fundamentally, however, both rationales depend upon an identical understanding of the manner in which such updating may acceptably take place-only through the intentional acts of a unitary legislature. ${ }^{78}$

Nineteenth-century judicial use of the presumption did not uniformly weaken it. During the nineteenth century, the Supreme Court also

76. See, e.g., Bowen v. Lease, 5 Hill 221, 225, n.a (N.Y. Sup. Ct. 1843).

77. See, e.g., Tracy v. Tuffly, 134 U.S. 206, 223 (1890) ("it is settled that, without express words of repeal, a previous statute will be held to be modified by a subsequent one, if the latter was plainly intended to cover the whole subject embraced by both, and to prescribe the only rules in respect to that subject that are to govern"); Cook County Nat'l Bank v. United States, 107 U.S. 445, 451 (1882) ("A law embracing an entire subject... may thus withdraw the subject from the operation of a general law as effectually as though, as to each such subject, the general law were in terms repealed."); Murdock v. City of Memphis, 87 U.S. 590, 617 (1874) ("We are of opinion that . . the new law embracing all that was intended to be preserved of the old, omitting what was not so intended, became complete in itself and repealed all other law on the subject embraced within it"); United States v. Jonas, 86 U.S. 598, 603 (1873) ("It is clear that this latter act was intended to qualify and limit the powers given by the act of 1830. It covers the whole subject... and embraces new and salutary provisions. ... [T]he latter act must operate as a repeal pro tanto of the act of 1830.”); see also infra Part III.B.

78. In the first edition of his treatise, Sutherland clarified the conceptualization of these two distinct methods of overcoming the presumption against implied repeals. Sutherland wrote:

[W]ill a revision repeal by implication previous statutes on the same subject, though there be no repugnance? The authorities seem to answer emphatically, Yes. The reasonable inference from a revision is that the legislature cannot be supposed to have intended that there should be two distinct enactments embracing the same subject-matter in force at the same time, and that the new statute, being the most recent expression of the legislative will, must be deemed a substitute for previous enactments.

SuTHERLAND, supra note 72, at 208. The Court and commentators appear to have considered this kind of repeal-by-comprehensive-revision an "implied repeal" even though in some cases the repealing statutes, like the nineteenth-century Revised Statutes and the early twentieth-century United States Code, included general repealing provisions for laws in the areas covered. Ralph $H$. Dwan \& Ernest $R$. Feidler, The Federal Statutes-Their History and Use, 22 MINN. L. REv. 1008, 1014-15, 1018 (1938). This bifurcation of the grounds on which implied repeal could be found reached its apotheosis in the Court's opinion in Posadas v. National City Bank, 296 U.S. 497 (1936):

There are two well-settled categories of repeals by implication-(1) where provisions in the two acts are in irreconcilable conflict, the later act to the extent of the conflict constitutes an implied repeal of the earlier one; and (2) if the later act covers the whole subject of the earlier one and is clearly intended as a substitute, it will operate similarly as a repeal of the earlier act.

Id. at 503 . 
sporadically articulated sub-rules pertinent to analysis of arguments that implied repeals had occurred in particular types of statutory conflict or particular substantive areas of law. For example, some opinions strengthened the presumption against implied repeals by showing that related canonsbased on similar assumptions regarding legislative coherence and intentwould support the same conclusion as that suggested by the presumption in particular cases. ${ }^{79}$ In the 1860 s and 1870 s, a series of opinions supported use of a strengthened presumption when implied repeal "would operate to the prejudice of the government," as, for example, by depriving it of revenue. $^{80}$ An earlier trend suggested that the presumption was similarly strengthened when the earlier statute had created property rights. ${ }^{81}$

Thus, although the nineteenth century saw considerable American elaboration of the presumption as inherited from and articulated by Coke, most of these elaborations did not depart radically from Coke's presentation of the principle. One could argue that the development of the comprehensive-revision rationale represented a retreat to a weaker form of the presumption. But this trend is best interpreted not as a change in the Court's fundamental understanding of its role as an honest agent of a legislature that could intend nothing but coherence, a role that Coke articulated as the basis of the presumption. Instead, it should be seen as a product of shifts in the Court's understanding of the nature of legislative intent, perhaps prompted by shifts in legislatures' avowed purposes during a period

79. See, e.g., The Cherokee Tobacco, 78 U.S. 616, 622 (1870) (Bradley, J., dissenting) (linking the presumption against implied repeals to the canon that specific laws are not to be construed as in conflict with more general laws); In re Distilled Spirits, 78 U.S. 356, 365 (1870) (linking the presumption against implied repeals to the rule that statutes in pari materia are to be construed together).

80. Kohlsaat v. Murphy, 96 U.S. 153, 154 (1877); Fabbri v. Murphy, 95 U.S. 191, 196 (1877); The Reform, 70 U.S. 617, 633 (1865); see also Graham v. Goodcell, 282 U.S. 409, 425 (1931) ("The familiar principle that repeal will not be implied unless there is a positive repugnancy ... has most appropriate application ... to the interpretation of laws for the collection of revenue ....").

81. In Rutherford v. Greene's Heirs, 15 U.S. 196 (1817), Justice Marshall wrote:

Whatever the legislative power may be, its acts ought never to be so construed as to subvert the rights of property, unless its intention so to do shall be expressed in such terms as to admit of no doubt.... [N]o silent, implied, and constructive repeals, ought ever to be so understood as to devest [sic] a vested right.

15 U.S. at 203. Marshall did not clarify the rationale for this conclusion, but it is surely based on both constitutional and reliance considerations. Although it would be relatively straightforward to propose a generalized reliance rationale for the presumption against implied repeals, very few opinions have done so. Cases possibly following this reasoning are Osborn v. Nicholson, 80 U.S. 654 (1871), and FTC v. A.P.W. Paper Co., 328 U.S. 193 (1946). Examples of later nineteenth-century cases involving property rights in which the Court found an implied repeal include Barney v. Dolph, 97 U.S. 652 (1878) (concluding that 1854 amendment to 1850 act providing for inheritance rights to land held by patent impliedly repealed portions of earlier act); United States $v$. Lynde, 78 U.S. 632 (1870) (concluding that 1860 act providing for adjustment of land-grant claims repealed by implication 1804 act declaring void earlier land grants); United States v. Vallejo, 66 U.S. 541 (1861) (concluding that 1824 colonization law repealed by implication earlier inconsistent law disposing of lands in Mexico). 
of widespread codification and revision. ${ }^{82}$ In other words, this period witnessed the emergence of new manifestations of legislative intent, in the form of codification and widespread statutory revision, but judicial understanding of the type of intent manifested through such legislative acts was not fundamentally different from the understanding of legislative omniscience and transtemporal coherence embraced by Coke. ${ }^{83}$

\section{1900-1985: The Persistence of Formalism}

The first three quarters of the twentieth century saw two parallel and related developments in the Court's use of the presumption. First, at the end of the nineteenth century and continuing well into the late twentieth, the Court began to rely heavily on extrastatutory indicia of legislative intent just as much as on the types of logical analysis advanced by Coke in determining whether the presumption was overcome in any given case. ${ }^{84}$ Toward the middle of the twentieth century, this approach took on a purposivist, rather than a traditionally intentionalist, character. ${ }^{85}$ At the same time, however, the Court's use of the presumption testified to the continuing and perhaps even intensifying force of formalistic reasoning in this area. Beginning around the 1930s, the Court became increasingly unwilling to find that an implied repeal had occurred. At the same time, the Court continued to develop doctrine in related areas by appealing to analogies with the presumption against implied repeals. In these analogical arguments, which became more widespread as the presumption was becoming increasingly difficult to overcome, the Court elevated the presumption to the status of a basic formal principle of legal reasoning.

A good example of the origins of both developments is the Court's 1891 opinion in Cope $v$. Cope. ${ }^{86}$ This case involved an apparent conflict between a series of statutes passed by the Utah territorial legislature allowing illegitimate children to inherit property and an 1862 federal antipolygamy statute, which annulled all existing Utah acts "that establish, support, maintain, shield, or countenance polygamy."87 The Supreme Court reconciled the statutes by interpreting the Utah laws as sheltering not the practice of polygamy but the offspring of polygamous marriages. ${ }^{88}$ The Court justified this conelusion by reference to Congress's purposes in

82. See generally Charles M. Cook, The American Codification Movement: A Study of ANTEBellum Legal ReForm (1981); PopKin, supra note 65, at 93-96.

83. The codification and revision movements might even be understood as a kind of selfconscious embracing by legislatures of the types of agency and intent that jurists imputed to them.

84. See ESKRIDGE, JR. ET AL., supra note 1, at 680-81.

85. This development arguably culminated in the Court's rejection of "formalistic" approaches to the reconciliation of statutes in Morton v. Mancari, 417 U.S. 535, 550 (1974).

86. 137 U.S. 682 (1891).

87. Id. at 686 (citing 12 Stat. 501 (1862)).

88. Id. at 687 . 
enacting the anti-polygamy statute, which the Court ascertained through examination of federal enactments subsequent to this statute. ${ }^{89}$ The Court thus reconciled the potentially conflicting laws not just through formalist demonstration of the logical possibility of their coexistence but through exposition of their deliberate creation as mutually supportive parts of a coherent statutory regime. ${ }^{90}$

Cope is also notable as an example of the second development mentioned above: a trend toward judicial reasoning by analogy to the presumption to support other types of resolution of statutory and legal conflict. The potentially conflicting laws at issue in Cope were enacted by different legislative bodies, not by the same legislature at different points in time. Such conflicts would now commonly be analyzed under the rubric of preemption doctrine, proceeding under the Constitution's Supremacy Clause. ${ }^{91}$ But the Court in Cope cited the presumption against implied repeals, not any presumption against preemption, to justify its reconciliation of the statutes. By this point, then, the Court had already begun to view the presumption as a rhetorical tool possessing enough force to justify its extension to other areas of statutory conflict. ${ }^{92}$

By focusing on subsequent legislative history in Cope and similar cases, ${ }^{93}$ the Court relied on an expansivc understanding of relevant legislative history. ${ }^{94}$ As in other areas of statutory interpretation, reliance on

89. Id. ("[W]hatever doubts there may be regarding the proper construction of this act, we think they are dispelled by a scrutiny of the subsequent legislation upon the same subject."). According to the Court, these subsequent acts, "dealing as they do with the same subject matter, should be construed not only as expressing the intention of Congress at the dates the several acts were passed, but ... also ... as legislative interpretations of the prior ones." Id. at 688 . The Court thus suggested that legislative purpose could be most reliably detected through examination of legislative behavior over a period of time. $I d$. at 689

90. The Court subsequently used an approach similar to the one it had used in Cope in analyzing potential conflicts betwcen federal statutes. See, e.g., Petri v. F.E. Creelman Lumber Co., 199 U.S. 487 (1905). The Court's opinion in this case describes a sequence of federal enactments and concludes that finding an implied repeal would "compel us to ignore the cntire course of legislation by Congress concerning the courts of the United States from the beginning, both prior to and after the adoption of the [putatively repealing act]." Id. at 498 . In neither Cope nor Petri did the presumption require the Court to reconcile statutes beyond the two that it was contended were in conflict. But in both cases, the Court did so anyway, as if to show that the ideal of legislative coherence underlying the presumption had not been disturbed by reconciliation of the statutes. This approach arguably suggests a weakening of the rationale for the presumption as presented by Coke. Although the Court continued to invoke the presumption as self-evident, the Court was no longer taking for granted the notion of legislative coherence that underlaid the use of the presumption.

91. U.S. ConST. art. IV, cl. 2; see generally infra Part IIl.A. In Cope, both the later-enactedstatute rule and the Supremacy Clause dictated the same result: in an irreconcilable conflict, the laterenacted federal statute would control.

92. On the relationship between preemption and repeal, see Nelson, supra note 59, at 250 (noting that the Supremacy Clause substituted a federal rule of priority for a temporal one, the later-enactedstatute rule).

93. See, e.g., Petri, 199 U.S. 487, discussed supra note 90

94. Ordinarily, examinations of legislative history to determine an enacting legislature's intent focus on the prehistory of an enacted law: drafts, committee reports, hearing transcripts, and so forth. 
legislative history in its current sense soon became part of the Court's repertoire in reconciling statutes to avoid implied repeal..$^{95}$ Perhaps the best example of this development is the Court's 1974 opinion in Morton v. Mancari..$^{96}$ This case remains one of the most frequently cited cases for the presumption against implied repeals, in part because it involved a particularly dramatic and functionalist reconciliation of two statutes that from a formalist, logical perspective appeared to prescribe irreconcilable results. ${ }^{97}$

The two statutes at issue in Morton v. Mancari were the 1934 Indian Reorganization Act (IRA), which provided for employment preferences for qualified Indians in the Bureau of Indian Affairs (BIA), and the Equal Employment Opportunity Act (EEOA) of 1972, which forbade discrimination in hiring and placement for competitive civil service positions within the federal government. ${ }^{98}$ Although the EEOA included exceptions to its terms in other areas, it included none for the BIA. ${ }^{99}$ Several non-Indian BIA employees challenged the validity of the IRA's preference provision in light of the EEOA. The district court concluded that the EEOA had repealed by implication that portion of the IRA providing for Indian preferences in BIA employment, applying a comprehensive-revision rationale and placing special emphasis on the absence of any IRA or BIA exemptions in the terms of the EEOA or in its legislative history. ${ }^{100}$

In his opinion for a unanimous Supreme Court, Justice Blackmun also examined legislative history but used it to reach the opposite result. The

Cope, in contrast, addressed subsequently-enacted laws to reach conclusions about the purposes of earlier-enacted laws.

95. See EsKridge, JR. ET AL., supra note 1, at 680-81, 937-1039; see also, e.g., Examining Bd. of Engineers v. Flores de Otero, 426 U.S. 572, 594 (1976) (expressing unwillingness to find implied repeal pro tanto "[i]n the absence of a change in the language of the ... provision or of affirmative evidence in the legislative history"); Morton v. Mancari, 417 U.S. 535, 550 (1974) (see infra notes 96103 and accompanying text); Otter Tail Power Co. v. United States, 410 U.S. 366, 372-75 (1973) (considering legislative history); United States v. Wise, 370 U.S. 405, 414 (1962) (examining Congressional Record); Laurens Fed. Sav. \& Loan Ass'n v. S.C. Tax Comm'n, 365 U.S. 517, 522 (1961) (examining timing of passage of the allegedly conflicting acts, as well as other elements of legislative history); United States v. E.I. du Pont de Nemours \& Co., 353 U.S. 586, 618 n.11 (1957) (Burton, J., dissenting) (examining Senate debates); Ex parte Republic of Peru, 318 U.S. 578, 585 n.4 (1943) (examining drafting history); United States v. Hutcheson, 312 U.S. 219, 246 (1941) (Roberts, J., dissenting) (citing "constant controversy and consideration in Congress" to argue against finding implied repeal); United States v. Noce, 268 U.S. 613, 617 (1925) (relying on committee report in determination of legislative intent).

96. 417 U.S. 535 (1974).

97. According to online citation services, as of this Comment's publication date, around 800 subsequent opinions cited Morton $v$. Mancari, most for its holding regarding implied repeal.

98. 417 U.S. at 537.

99. Mancari v. Morton, 359 F. Supp. 585, 590 (D.N.M. 1973) ("[T]here were exceptions placed in [the EEOA], so Congress considered limitations on its scope, but none was included as to the Bureau of Indian Affairs."), rev'd, 417 U.S. 535 (1974).

100. Id. 
Court reasoned that the statutes' respective legislative histories showed that the statutes had different purposes ${ }^{101}$ :

The preference is a longstanding, important component of the Government's Indian program. The anti-discrimination provision, aimed at alleviating minority discrimination in employment, obviously is designed to deal with an entirely different and, indeed, opposite problem. Any perceived conflict is thus more apparent than real. ...

... Any other conclusion can be reached only by formalistic reasoning that ignores both the history and purposes of the preference and the unique legal relationship between the Federal Government and tribal Indians. ${ }^{102}$

The Court thus concluded that, whatever logical contradiction might appear to exist between the verbal commands of the two statutes, their fundamental purposes were not in conflict.

Despite its disavowal of the district court's "formalistic" approach, at root the Supreme Court in Morton v. Mancari remains faithful to the formalist imperative exemplified by Coke and by the district court. The Court eschews the use of formalist reasoning in demonstrating the presence or absence of contrariety between two statutes, but it does not reject the basic rule that triggers the need for such a demonstration: if a contradiction is present, an implied repeal will occur, but if there is no contradiction, the statutes both stand. This binary, absolutist rule, despite the opportunities it provides for interpretive creativity, is a highly formalist principle of interpretation. ${ }^{103}$ Moreover, the Court's reasoning in Morton v. Mancari is exceptionally faithful to the anti-updating, preservationist policy underlying the presumption. ${ }^{104}$

Morton $v$. Mancari confirms that, although in the twentieth century the Court began self-consciously to apply a more functionalist approach to the reconciliation of statutes in the service of the presumption against implied repeals, the presumption itself remained highly formalist in character. An examination of the areas in which the Court reasoned by analogy to the presumption against implied repeals in the twentieth century reinforces this

101. 417 U.S. at $541-47$.

102. Id. at 550 .

103. See Carlos E. Gonzalez, The Logic of Legal Conflict: The Perplexing Combination of Formalism and Anti-Formalism in Adjudication of Conflicting Legal Norms, 80 OR. L. REv. 447, 46874 (2001).

104. The Court implicitly framed its conclusion as the result of a choice between two types of statutory incoherence. If the preference provision were removed from the IRA, the coherence of that particular statutory sub-scheme would be disturbed. If, on the other hand, the preference provision were to remain, the EEOA would acquire an apparent exccption beyond those in its text and become partly incoherent. In choosing the latter option, the Court suggested that it is preferable to preserve the coherence of a longstanding scheme than to ensure the cohcrence of a scheme of more recent origin. 417 U.S. at 550. In this way, the Court's use of the presumption in Morton v. Mancari suggests a more comprehensive anti-updating bias than do some earlier examples of the presumption's use. 
conclusion. In several opinions in the 1940s and 1950s, Justices Stone and Harlan followed the pattern set in Cope by appealing to the presumption against implied repeals in arguing for a presumption against federal preemption of state law. ${ }^{105}$ These opinions did not acknowledge any difficulty in applying a guideline based on the presumed consistency of a single legislature's intent to a situation involving conflicts between statutory schemes created by legislatures distinct not only temporally but in political scope. Instead, the opinions appeal to the presumption as a basic rule against conclusions of statutory inconsistency.

In another line of cases, the Court confronted conflicts between the statutory scheme established by the antitrust laws and subsequently enacted schemes for the regulation of certain industries. ${ }^{106}$ In each case, industry defendants who had been sued under the antitrust laws argued that the regulatory schemes exempted them from liability. Strictly speaking, these cases turned on whether particular regulatory schemes rendered the antitrust laws inapplicable in particular situations, not on whether those regulatory schemes required parts of the antitrust laws to be deemed generally inoperative. Nevertheless, the Court repeatedly described such exemptions as implied repeals. ${ }^{107}$ Like the use of the presumption against implied repeals to argue for a presumption against preemption, this approach involved a simplification of the presumption against implied repeals into a rule forbidding the disturbance of existing statutory schemes. ${ }^{108}$

105. Pub. Util. Comm'n v. United States, 355 U.S. 534, 547 (1958) (Harlan, J., dissenting); Penn Dairies v. Milk Control Comm'n, 318 U.S. 261, 275 (1943) (Stone, J.) ("An unexpressed purpose of Congress to set aside statutes of the states regulating their internal affairs is not lightly to be inferred. ... Considerations whieh lead us not to favor repeal of statutes by implication should be at least as persuasive when the question is one of the nullification of state power by Congressional legislation.") (citation omitted); Cloverleaf Butter Co. v. Patterson, 315 U.S. 148, 177 (1942) (Stone, J., dissenting) (same).

106. See, e.g., United States v. Phila. Nat'l Bank, 374 U.S. 321,350 (1963) (leading case); see also Square D. Co. v. Niagara Frontier Tariff Bureau, 476 U.S. 409, 421 (1986); Otter Tail Power Co. v. United States, 410 U.S. 366, 372-75 (1973); Hughes Tool Co. v. Trans World Airlines, 1ne., 409 U.S. 363, 393 (1973) (Burger, J., dissenting); Kaplan v. Lehman Bros., 389 U.S. 954, 957 (1967) (Warren, J., dissenting); Camation Co. v. Pae. Westbound Conf., 383 U.S. 213, 218 (1966); Silver v. N.Y. Stock Exch., 373 U.S. 341, 347 (1963) ("The fundamental issue confronting us is whether the Securities Exchange Act has created a duty of exchange self-regulation so pervasive as to constitute an implied repealer of our antitrust laws"); Pan Am. World Airways, Inc. v. United States, 371 U.S. 296, 320 (1963) (Brennan, J., dissenting) ("[O]f the instruments of accommodation that are available, pro tanto repeal of the antitrust laws by implication from a regulatory statute . . is surely the very last that ought to be resorted to."); United States v. E.1. Du Pont de Nemours \& Co., 353 U.S. 586, 618 n.11 (1957) (Burton, J., dissenting) (noting use of the term "implied repeal" in the context of antitrust exemptions in Senate debates); Georgia v. Pa. R.R. Co., 324 U.S. 439, 457 (1945) (using language of "repugnancy," but not "implied repeal"); United States v. Borden Co., 308 U.S. 188, 198 (1939).

107. "Repeals of the antitrust laws by implication from a regulatory statute are strongly disfavored" was one of the most commonly repeated formulations of this hybrid rule. Phila. Nat'l Bank, 374 U.S. at 350.

108. Academic commentary on the presumption, which experienced a minor flowering during the 1930 s to 1950 s, also reflected these formalistic tendencies. See commentaries cited supra note 8 . 
The emergence of these analogical uses of the presumption in the twentieth century coincided with a decrease in the Court's willingness to find that an implied repeal had occurred..$^{109}$ Because of the presumption's anti-updating bias, its strengthening and simplification over this period might suggest an increasing hostility to the notion of statutory updating. But over this same period, as noted above, the Court was generally taking a more purposive approach to describing the coherence of the statutory scheme, and commentators were beginning to pay increased attention to the complex nature of the legislative process. ${ }^{110}$ These practices and inquiries worked against the traditional rationale for the presumption - the notion that legislatures could be understood to act with a single institutional will and to update the statutory scheme only intentionally. To the extent that this rationale is descriptive, these new approaches seemed to show that the rationale is mistaken. ${ }^{11}$ To the extent that the notion is normative and requires courts to impose a hypothetically intended coherence on the statutory scheme, it is in some tension with the policy of legislative deference in whose service courts ostensibly use formalist rules such as the presumption. ${ }^{12}$ As the next section shows, in recent decades the Court has shied away from confronting this problem with the rationale for the presumption and instead has simplified the presumption into a hard-and-fast rule largely lacking a rationale.

\section{The Supreme Court's Use of the Presumption Since the 1980s:} The Emergence of an Inflexible Rule

In recent decades, the presumption against implied repeals, as used by the Supreme Court, seems to have evolved into a virtual rule against implied repeals. Between 1986 and 2003, the Court addressed the question of a potential implied repeal in at least twenty-five cases. ${ }^{113}$ However, the Court concluded that an implied repeal had occurred in at most two of these cases. In these two cases, Argentine Republic v. Amerada Hess Shipping Corp. ${ }^{114}$ and Branch v. Smith, ${ }^{115}$ the Court rejected the argument that an implied repeal had occurred but concluded that the statutory scheme had been updated anyway. This peculiar practice suggests that the most

109. Between 1900 and 1909 , the Court found or agreed that an implied repeal had occurred in five of seventeen cases in which it considered the question. Between 1910 and 1919 , the ratio was 8/24; between 1920 and 1929,3/14; between 1930 and 1939, 0/11; between 1940 and 1949, 0/13; between 1950 and 1959, 1/8; between 1960 and 1969, $1 / 11$; and between 1970 and 1979, 2/22. See Appendix.

110. See generally HART \& SACKS, supra note 14, at 693-1007; ESKRIDGE, JR. ET AL., supra note 7 , at 690-700.

111. See, e.g., ESKRIDGE, JR. ET AL., supra note 1, at 216-18; ESKRIDGE, JR., supra note 11, at 14; Eskridge, Jr. \& Frickey, supra note 11, at 326-27, 333-35.

112. See discussion supra Part I.B; see also Buzbee, supra note 54.

113. See Appendix for a list of these cases.

114. 488 U.S. $428,437-38$ (I989).

115. 538 U.S. $254,273-76,304-05(2003)$ 
recent development in the Court's use of the presumption may be conceptualized as a shift in the Court's usage of the term "implied repeal." Some justices on the Court-unlike other courts ${ }^{116}$ and current treatises on the subject $t^{117}$ now appear to use this phrase as a purely pejorative term for a result that is by definition undesirable. ${ }^{118}$

In Amerada Hess, ${ }^{119}$ the Court considered the arguably contradictory jurisdictional commands of the Alien Tort Statute (ATS) of I789 120 and the Foreign Sovereign Immunities Act (FSIA) of $1976 .{ }^{121}$ The plaintiffs, two Liberian shipping corporations, sued the Argentine Republic over damage to their ships. They argued that the ATS provided a basis for district court

116. California appellate courts, for example, have not elevated the presumption to the status of a categorical rule. See infra note 150.

117. See infra notes $148,149,151-53$ and accompanying text.

118. Justices Scalia and Thomas both appear willing to use the term as shorthand for a forbidden conclusion. In his dissenting opinion in Shalala v. Illinois Council on Long Term Care, for example, Justice Scalia relied on the presumption against implied repeals in arguing that the majority opinion inappropriately overrode the Court's own prior interpretation of the same statutory scheme. 529 U.S. 1, 32 (2000) (Scalia, J., dissenting) ("There is in my view ... (since repeals by implication are disfavored) [no] basis for holding that the subsequent addition of a judicial-review provision ... altered the meaning we had authoritatively pronounced."). Compare Justice Scalia's majority opinion twelve years earlier in United States v. Fausto, 484 U.S. 439 (1988), in which he expressly rejected the notion that the presumption against implied repeals could apply to judicial "repcals" of earlier judicial interpretations of statutes. Id. at 453. In Fausto, Justice Scalia wrote:

Repeal by implication of an express statutory text is one thing. . . But repeal by implication of a legal disposition implied by a statutory text is something else. The courts frequently find Congress to have done this-whenever, in fact, they interpret a statutory text in the light of surrounding texts that happen to have been subsequently enacted. This classic judicial task of reconciling many laws enacted over time, and getting them to "make sense" in combination, necessarily assumes that the implications of a statute may be altered by the implications of a later statute. And that is what we have here.... All that we find to have been "repealed" by the [more recent statute] is the judicial interpretation of the [earlier statute] - or, if you will, the [earlier statute's] implication.

Id. Read together, these opinions suggest that Justice Scalia is willing to rely on the presumption and to use the term "implied repeal" analogically and casually to discredit a conclusion with which he does not agree, but that he may take care to explain how the presumption is an inapposite principle when its analogical use would weigh against a conclusion that he has reached on other grounds.

In his dissenting opinion in Henderson v. United States, 517 U.S. 654 (1996), Justice Thomas remarked that the majority in that case failed to clarify whether its conclusion-that one of the Federal Rules of Civil Procedure superseded a jurisdictional statute-was based on the Rules Enabling Act, 28 U.S.C. $\$ 2072$, or on a theory of implied repeal. 517 U.S. at 679 (Thomas, J., dissenting) ("[I]t appears that the majority may... find that Rule 4(j) effected an implied repeal of [the jurisdictional statute] independent of the Rules Enabling Act... Regardless of the rubric under which this case is actually decided, the Court, in my opinion, reaches the wrong conclusion."). Justice Thomas suggested that an argument of implied repeal amounts to "rewrit[ing] a statute when the text does not... generate an outcome that we desire." Id. Notably, however, Justice Thomas did not reconcile the two provisions at issue to demonstrate why an implied repeal could not have been held to have occurred. Compare his majority opinion in J.E.M. AG Supply, Inc. v. Pioneer Hi-Bred Int'l, Inc., 534 U.S. 124, $141-44$ (2001), in which he executed a textbook example of the kind of formalist, logical reconciliation Coke performed in Dr. Foster's Case in order to avoid a conclusion of implied repeal.

119. 488 U.S. 428 (1989).

120. 28 U.S.C. $\S 1350(2000)$.

121. 28 U.S.C. $\$ 1330(2000)$. 
jurisdiction over their suit. ${ }^{122}$ The Argentine Republic argued that the more recent FSIA barred the action, since the FSIA provides that "a foreign state shall be immune from the jurisdiction" of U.S. courts. ${ }^{123}$ Using the language of preemption rather than that of the presumption against implied repeals ${ }^{124}$ and relying on legislative history to ascertain the purposes of the FSIA, the Second Circuit concluded that the FSIA did not alter U.S. federal court jurisdiction under the ATS. ${ }^{25}$

The Supreme Court reversed, reasoning that the FSIA's terms displaced whatever jurisdiction over this sort of suit the ATS might once have permittcd. ${ }^{126}$ The Court thus concluded that the FSIA had effectively updated that portion of the statutory scheme addressing federal court jurisdiction. But though the Court explicitly reasoned that the FSIA had effected a comprehensive revision of this portion of the statutory scheme, it firmly rejected the applicability of the presumption against implied repeals to this case:

We think that Congress' failure in the FSIA to enact an express pro tanto repealer of the Alien Tort Statute speaks only faintly, if at all, to the issue involved in this case. In light of the comprehensiveness of the statutory scheme in the FSIA, we doubt that even the most meticulous draftsman would have concluded that Congress also needed to amend pro tanto the Alien Tort Statute and presumably ... other grants of subject-matter jurisdiction in Title 28. ...

... [W]e are not persuaded by [Amerada Hess's] arguments based upon the rule of statutory construction under which repeals by implication are disfavored. This case does not involve two statutes that readily could be seen as supplementing one another, ... nor is it a case where a more general statute is claimed to have repealed by implication an earlier statute dealing with a narrower subject. ... Congress' decision to deal comprehensively with the subject of foreign sovereign immunity in the FSIA, and the express provision in [the FSIA for foreign states' sovereign immunity,] ... preclude a construction of the Alien Tort Statute that permits the instant suit. ${ }^{127}$

The Court's language here makes it possible to read Amerada Hess simply as a rejection of the applicability of the label "implied repeal" to a situation

122. The ATS provides for original district court jurisdiction over torts committed by aliens "in violation of the law of nations or a treaty of the United States." 28 U.S.C. $\S 1350$, cited in 488 U.S. at 432.

123. 488 U.S. at 434 (eiting 28 U.S.C. $\$ 1604(2000)$ ).

124. Amerada Hess Shipping Corp. v. Argentine Republic, 830 F.2d 421, 427 (2d Cir. 1987) (noting and rejecting Argentina's view that "the FSlA preempts the jurisdictional grant of the Alien Tort Statute"), rev'd, 488 U.S. 428 (1989).

125. Id. at 427 (eiting H.R. REP. No. 94-1487, reprinted in 1976 U.S.C.C.A.N. 6604)

126. 488 U.S. at $437-38$.

127. Id. 
in which a broadly sweeping enactment has widespread repealing effects. Such a situation, involving a legislative effort to update the statutory scheme comprehensively, closely resembles that of implied repeal by comprehensive revision. ${ }^{128}$ But the opinions in a more recent Supreme Court case, Branch $v$. Smith, make this understanding of the reasoning in Amerada Hess difficult to defend. ${ }^{129}$ In Branch $v$. Smith, three different justices writing three different opinions cited as the leading case for the definition of implied repeal ${ }^{130}$ Posadas $v$. National City Bank of New York, a 1936 case expressly recognizing both repugnancy and comprehensive revision as mechanisms of implied repeal. ${ }^{131}$

Branch v. Smith, by far the Court's most extensive recent treatment of an implied repeal question, highlights the problems with the Court's current use of the presumption. The case involved a conflict between two statutes addressing voting redistricting procedures. The older statute, 2 U.S.C. $\S 2 \mathrm{a}(\mathrm{c})(5)$, dates from $194 \mathrm{I}$ and provides that if a decrease in the number of representatives apportioned to a state results in a greater number of districts than representatives, the representatives "shall be elected from the State at large" "[u]ntil [the] State is redistricted in the manner provided by law thereof after any apportionment."132 The newer statute, 2 U.S.C. $\S 2 \mathrm{c}$, was a rider to a private bill enacted in $1967^{133}$ and provides that in any state entitled to more than one representative after reapportionment, "there shall be established by law a number of districts equal to the number of Representatives to which such State is so entitled." 134 After the Mississippi judiciary and legislature failed to redistrict the recently reapportioned state in what a federal district court determined to be a timely fashion, the

128. In Amerada Hess, the Court cited four cases as authority for its rejection of the applicability of an argument based on the presumption against implied repeals. 488 U.S. at 438 . All four, listed here in the order in which the Court cited them, are cases addressing an asserted statutory repugnancy: Wood v. United States, 41 U.S. 342, 363 (1842) (for implied repeal to rcsult, "[t]here .. ought to be a manifest and total repugnancy in the provisions"); Morton v. Mancari, 417 U.S. 535, 549-51 (1974) (sce supra notes 96-103 and accompanying text); Red Rock v. Henry, 106 U.S. 596, 601-03 (1883) (noting a comprehensive-revision rationale but deciding casc on grounds of absence of repugnancy); United States v. Tynen, 78 U.S. 88, 92-93 (1870) ("When repugnant provisions ... exist bctween two acts, the latter act is held, according to all the authorities, to operate as a repeal of the first act, for the latter act expresses the will of the government as to the manner in which the offences shall be subsequently treated"). The Court in Amerada Hess does not acknowledgc the implied repeal scheme set out in Posadas v. National City Bank, 296 U.S. 497 (1936), described supra note 77.

129. 538 U.S. 254 (2003).

130. Each of the justices writing a substantial opinion in Branch v. Smith cites Posadas as the leading case for the definition. Id. at 273, 285, 293 (opinions of Scalia, Stevens, \& O'Connor, JJ., respectively).

131. 296 U.S. 497,503 (1936).

132. 2 U.S.C. $\$ 2 \mathrm{a}(\mathrm{c})(5)(2000)$, quoted in Branch v. Smith, 538 U.S. at 268.

133. See Branch v. Smith, 538 U.S. at 289-90 (Stevens, J., dissenting) (discussing legislative history of 2 U.S.C. $\S 2$ c).

134. 2 U.S.C. $\$ 2 c$, quoted in Branch v. Smith, 538 U.S. at 267. 
district court issued its own redistricting plan. ${ }^{135}$ In reviewing this action, the Supreme Court focused mainly on two related questions. First, it asked whether the district court's issuance of the redistricting plan would have been lawful under the later enactment, considered alone. It then asked whether the district court should have ordered at-large elections under $\S 2 \mathrm{a}(\mathrm{c})(5)$ or composed a redistricting plan under $\S 2 \mathrm{c}$. In other words, the Court considered whether $\S 2 \mathrm{c}$ 's redistricting command had impliedly repealed $\S 2 \mathrm{a}(\mathrm{c})(5)$ 's apparent command that courts order at-large elections after reapportionment until the state becomes redistricted "in the manner provided by the law."136

A seven-justiee majority agreed that $\S 2 \mathrm{c}$ gave the district court power to issue a redistricting plan, rejecting the argument that $\S 2 c$ 's reference to redistricting "in the manner provided by law" envisioned legislative action only. ${ }^{137}$ The Court split severely, however, over whether $\S 2 \mathrm{c}$ had impliedly repealed $\S 2 \mathrm{a}(\mathrm{c})(5)$. Justice Scalia, writing the lead opinion, applied the presumption as a rule and performed an elaborate reconciliation of the two statutes that made the district court's proceeding under $\S 2 \mathrm{c}$ rather than $\S 2 \mathrm{a}(\mathrm{c})(5)$ lawful. ${ }^{138}$ His reconciliation rendered $\S 2 \mathrm{a}(\mathrm{c})(5)$ binding on courts only when elections are "so imminent that no entity" could redistrict "without disrupting the election process."139

This interpolation into the text of the older statute persuaded only a plurality of the Court. Both Justice Stevens, who concurred in the judgment, ${ }^{140}$ and Justice O'Connor, who dissented from this part of the lead opinion, criticized Justice Scalia's interpretive reconciliation as "tortured judicial legislation." 141 Justice Stevens, writing for three justices, reasoned that $\S 2 \mathrm{c}$ had in fact impliedly repealed $\S 2 \mathrm{a}(\mathrm{c})(5)$, so that at-large elections would never be required. ${ }^{142}$ In contrast, Justice O'Connor concluded that given the circumstances the district court should have ordered at-large elections under the command of $\S 2 \mathrm{a}(\mathrm{c})(5) \cdot{ }^{143}$ In Justice O'Connor's view, Justice Scalia's reconciliation of the statutes amounted to an implied repeal "sub silentio,"144 and Justice Stevens's conclusion paid insufficient heed to

135. Branch v. Smith, 538 U.S. at 255-61.

136. 2 U.S.C. $\$ 2 \mathrm{a}(\mathrm{c})(5)$, quoted in Branch v. Smith, 538 U.S. at 268.

137. See Part 111-A of Justice Scalia's opinion, Branch v. Smith, 538 U.S. at 266-72 (joined by Rehnquist, C.J., Stcvens, Kennedy, Souter, Ginsburg \& Breyer, JJ.).

138. See Part 11I-B of Justice Scalia's opinion, $i d$. at 273-76 (joined by Rehnquist, C.J., Kennedy \& Ginsburg, JJ.).

139. Id. at 275 .

140. Id. at 292 (Stevens, J., concurring) (joined by Souter \& Breyer, JJ.) (referring to the plurality's "tortured judicial legislation to preserve a remnant of an obsolete federal statute").

141. Id. at 298 (O'Connor, J., dissenting) (joined by Thomas, J.) (quoting with approval Stevens's characterization of the plurality opinion as "tortured judicial legislation").

142. Id. at 285 (Stevens, J., concurring).

143. Id. at 310 (O'Connor, J., dissenting).

144. Id. at 304-05. In support of her rejection of Justice Scalia's interpretation, Justice O'Connor cites three different writings on statutory interprctation by Justice Scalia himself. Id. at 298-99 (citing 
the presumption against implied repeals and the deeper history of the statutory scheme. $^{145}$

This alignment shows that, while three current justices are willing to use the term "implied repeal" to refer to a permissible type of statutory updating, ${ }^{146}$ six perceive the presumption as an absolute rule and implied repeals as virtually forbidden. ${ }^{147}$ More important, the opinions in Branch $v$. Smith also show that the results of applying this absolute rule will not be predictable. Justice Scalia and the other members of the plurality give the presumption so much weight that it prevents an instance of statutory updating from being called an implied repeal. Yet Justice Scalia's interpretation updates the statutory scheme nevertheless, resulting in application of the more recent statute in most circumstances where the earlier statute would formerly have applied. Justices O'Connor and Thomas also treat the presumption as a rule, but they take its anti-updating policy more seriously, narrowing the reach of a recent statute to allow it to coexist with an older one. Both of these results seem undesirable, Justice Scalia's because it is not candid and Justice O'Connor's because it is arguably countermajoritarian. Together, the approaches create a further problem: unyielding adherence to the presumption against implied repeals can support diametrically opposed results, undermining any formalist justification for the canon.

The Court's current position is even more striking when contrasted with attitudes toward implied repeal exhibited elsewhere. For example, the principal American treatise on statutory construction continues to describe implied repeal as a perfectly acceptable result, ${ }^{148}$ and the leading British treatise on the subject offers similar guidance. ${ }^{149}$ This rejection of an absolute rule against implied repeals also reflects judicial practice in at least some courts. Since 1986, state appellate courts in California, for example, have found an "implied repeal" in seven of forty-six cases considering the question. ${ }^{150}$ This ratio demonstrates the presumption's continued strength but does not suggest that it is irrebuttable.

Scalia, supra note 27, and Holloway v. United States, 526 U.S. 1, 14 (1999) (Scalia, J., dissenting)); id. at 304 (citing Scalia, supra note 11).

145. Id. at 295-97 (O'Connor, J., dissenting) (discussing history of districting laws).

146. Justices Breyer, Souter, and Stevens.

147. Chief Justice Rehnquist and Justices O'Connor, Scalia, Kennedy, Thomas, and Ginsberg.

148. "[W]here a consistent body of laws cannot be maintained without the abrogation of a previous law, a repeal by implication of previous legislation ... is readily found in the terms of a later enactment." SINGER, supra note $1, \S 23: 9$, at 467 (citing eases).

149. In this treatise, Francis Bennion writes: "The possibility of implied repeal goes wider ... than is indicated by the principle of contradiction. Other interpretative criteria may implicate implied repeal, for example the commonsense construetion rule [which presumes that the legislator intended eommon sense to be used in construing the statute]." Francis Bennion, Statutory Interpretation: A Code 225 (3d ed. 1997).

150. See People v. Morante, 975 P.2d 1071 (Cal. 1999); County of Santa Barbara v. Connell, 72 Cal. App. 4th 175, 186 (1999); People v. Bustamante, 57 Cal. App. 4th 693, 698 (1997) ("repeal, albeit 
Moreover, at least one judge has explicitly outlined the dangers of uncritical and overly strict application of the presumption. Judge Posner, writing for the Seventh Circuit in 1987, remarked that the presumption rests on an "unrealistic premise about the legislative process"-namely, that legislatures are aware of all of the statutes that their more recent enactments might displace, and intend no such displacement. ${ }^{151}$ While Judge Posner acknowledges the formalist appeal of the canon, ${ }^{152}$ he has elsewhere reiterated the impossibility of justifying rigid application of the canon by reference to principles of legislative supremacy. ${ }^{153}$ Rigid use of the canon, which favors the integrity of older statutes over that of more recent ones, is indefensible both empirically (because, as Posner points out, it is unrealistic to assume that legislatures would prefer that their more recent

by implication"); Corona-Norco Unified Sch. Dist. v. City of Corona, 13 Cal. App. 4th 1577 (1993); Estate of Damskog, 1 Cal. App. 4th 78 (1991); Sanford v. Garamendi, 233 Cal. App. 3d 1109 (1991); Selinger v. City Council, 216 Cal. App. 3d 259 (1989).

151. Judge Posner wrote:

Like so many such maxims ... this one rests on an unrealistic premise about the legislative process. The premise is that when a legislature contemplates passing a new statute it is careful to search the statute book for any statute that might overlap the new one, and if it finds any such older statute and doesn't want to continue that statute in force it repeals it explicitly when passing the new one.... But, of course, neither Congress nor any other legislature in the United States "envision[s] the whole body of the law when it enacts new legislation." How could it, given the vast expanse of legislation that has never been repealed and the even vaster expanse of judicial and administrative rulings glossing that legislation?

Edwards v. United States, 814 F.2d 486, 488 (7th Cir. 1987) (citation omitted). Judge Posner went on to apply the presumption neverthcless, bowing to a "mood [expressed by thc Supreme Court in cases regarding the application of the presumption to penal statutes] that we are not free to ignore." Id. at 489.

152. In Friedrich v. City of Chicago, 888 F.2d 511 (7th Cir. 1989), vacated by 499 U.S. 933 (1991), Judge Posner wrote:

[T] he best that can be said for the canon against repeals by implication is . . that it provides a mechanical rule for deciding difficult cascs and thus makes law simpler and curbs judicial discretion, and ... that it encourages legislators and their staffs to do a thorough search of previous statutes before enacting a new one. The first point identifies real, although limited, social goods ... but the second strikes us as unrealistic about the conditions under which legislatures work.

Id. at 516 .

153. See Posner, supra note 8 . In this article, Judge Posner considers two possible rationales for the presumption and concludes that neither is supportable:

Consider now the ... canon that repeals by implication are not favored, and imagine what the idca behind it might be. Maybe it is that whenever Congress enacts a new statute it combs the United States Code for possible inconsistencies with the new statute, and when it spots one, it repeals the inconsistency explicitly. But this would imply legislative omniscience in a particularly uncompromising and clearly unrealistic form, for if Congress could foresee every possible application of a new statute and make provision for it, there would be no need for judicial interpretation at all. . .

An alternative basis for this canon is the idea that if the choice is between giving less scope to the new statute and cutting down the intended scope of the old (because both cannot be enforced fully without conflict), Congress must desire the courts to do the first. But there is no basis for this imputation of congressional purpose, and the opposite inference is if anything more plausible - that the enacting Congress cares more about its statutes than thosc of previous Congresses.

Id. at $812-13$. 
enactments give way to older ones) and normatively (to the extent that such use of the canon frustrates the legislature's attempts to update the statutory scheme).

Both the willy-nilly deployment of the presumption in Branch $v$. Smith and this disparity between the Supreme Court's recent approach and the attitudes of treatises and other courts toward the principle reveal a disturbing lack of consensus regarding the reasons for use of the presumption. This situation arises from a combination of factors. The traditional intentionalist justifications for the presumption, which were never very clearly delineated in the first place, no longer seem theoretically sound. But no rationale has been advanced to take their place. Thus, although it masquerades as a policy-based guideline, the presumption is actually a rule without any principled basis. Nevertheless, the presumption remains quite usefulnot as a mechanism for signaling consistency to legislatures, but as an assertion that the invoking court is refraining from disturbance of the statutory scheme. Using the presumption for this purpose has allowed the Supreme Court to signal interpretive passivity and self-consciousness of its countermajoritarian role when it is at its most active-as when, for example, it is approving the federal judiciary's exercise of powers that should arguably be reserved to a state, which was the result of Branch v. Smith. ${ }^{154}$

If the canon is to serve the desirable functions of promoting legislative supremacy and encouraging legislative clarity, this situation should be remedied. As a preliminary step in formulating a solution, this Comment next looks at the practices that courts, and the Supreme Court in particular, have developed to reconcile other types of conflicts involving statutes.

\section{III \\ Other Conflict-Resolution Doctrines}

\section{A. Preemption Doctrine}

In addition to conflicts between the Constitution and statutes, ${ }^{155}$ and between statutes enacted by the same legislature at different times, courts in a federal system may face conflicts between laws enacted by federal legislatures and those enacted by state legislatures. Preemption doctrine is the set of rules that courts have developed to govern their handling of these conflicts. As noted above in Part II.C, the Supreme Court has suggested a congruence between the conflicts at issue in a case of potential preemption and the conflicts at issue in a situation of potential implied repeal. ${ }^{156}$ For

154. See 538 U.S. 254, 279-80, 301-04 (2003) (addressing whether the result of the case violates anticommandeering principles).

155. See supra note 45 .

156. See supra note 105 and accompanying text; see also Nelson, supra note 59, at 230 (" $[\mathrm{T}]$ he Supremacy Clause puts questions about whether a federal statute displaces state law within the same framework as questions about whether one statute repeals another."). 
the purposes of developing a new rationale for the presumption against implied repeals, the analogies between these two types of statutory conflict are illuminating, but attention to the differences between these doctrines of statutory conflict resolution is equally important.

In establishing rules for the resolution of conflicts between state and federal laws, preemption doctrine, unlike the presumption against implied repeals, starts with the Constitution. ${ }^{157}$ Under the Supremacy Clause, if a federal law enacted "in Pursuance" of the Constitution "coll[ides]" with state law, the federal law prevails regardless of its temporal relationship to the state law with which it conflicts. ${ }^{158}$ Judicial decisions about preemption based on the Supremacy Clause therefore largely ignore the updating issues inherent in most other rules surrounding legal conflict resolution. ${ }^{159}$ Instead, preemption doctrine seeks to "define the sphere of control between federal and state law when they conflict, or appear to conflict." 160

Courts have recognized three ways in which federal law may prevail over state law: express preemption, implied field preemption, and implied conflict preemption, which in turn may consist of actual conflict preemption or of "obstacle" preemption. ${ }^{161}$ The following discussion focuses on the doctrines relating to implied preemption, which are structurally quite similar to the doctrines surrounding implied repeal discussed above. ${ }^{162}$

Implied field preemption is an intentionalist doctrine, directing a court to conclude that federal law preempts state law when the court finds evidence of Congress's "intent to occupy a given field," and when the state law falls within this field. ${ }^{163}$ This doctrine recalls the comprehensiverevision theory of implied repeal discussed in Part II.B. Implied conflict preemption, in contrast, is a bifurcated doctrine with both formalist and purposivist elements. First, when federal and state law "actually conflict[],"

157. The Supremacy Clause provides in part that the "Constitution, and the Laws of the United States ... made in Pursuance thereof... shall be the supreme Law of the Land; and the Judges in every State shall be bound thereby, any Thing in the Constitution or Laws of any State to the Contrary notwithstanding." U.S. CoNST. art. Vl, cl. 2.

158. See Gibbons v. Ogden, 22 U.S. 1, 210 (1824) ("[T] whether the laws of New-York... have ... come into collision with an act of Congress.... Should this collision exist, ... the acts of New-York must yield to the law of Congress . . ..").

159. See Nelson, supra note 59, at 250 ("[T]he Supremacy Clause substitutes a federal rule of priority for the traditional temporal rule of priority.").

160. Mary J. Davis, Unmasking the Presumption in Favor of Preemption, 53 S.C. L. Rev. 967, 968 (2002).

161. See, e.g., Silkwood v. Kerr-McGee Corp., 464 U.S. 238, 248 (1984); Nelson, supra note 59, at $227-29$.

162. Express preemption provisions raise distinct questions about courts' interpretive freedom and adherence to the principle of legislative supremacy. Courts sometimes apply the presumption against preemption discussed in the text to construe express preemption provisions narrowly. See Nelson, supra note 59 , at $226-27 \&$ n.8.

163. Silkwood, 464 U.S. at 248; see also Davis, supra note 160, at 974-75 (examining S. Ry. Co. v. Reid, 222 U.S. 424 (1912); N.Y. Cent. R.R. Co. v. Winfield, 244 U.S. 147 (1917)). 
"state law is ... pre-empted." 64 This rule resembles the formalist version of the repugnancy rationale for implied repeal. Second, courts may find that preemption has occurred when "the state law stands as an obstacle to the accomplishment" of the legislature's purposes in enacting the federal law. ${ }^{165}$ This rule mirrors the approach to resolution of implied-repeal conflicts best exemplified by the Court's functional purposivist approach in Morton v. Mancari. ${ }^{166}$

As noted above, in part in reliance on analogies with the presumption against implied repeals, the Court has repeatedly invoked a presumption against preemption. ${ }^{167}$ This presumption reflects conflict-avoidance and coherence norms akin to those embodied in the presumption against implied repeals. However, in keeping with the broad range of types of preemptive conflict that the Court has been willing to recognize, the presumption against preemption does not enjoy the near-categorical status that the presumption against implied repeals currently does on the Supreme Court. ${ }^{168}$ Many recent Supreme Court preemption opinions acknowledge the prcsumption but quickly conclude that it is inapplicable. ${ }^{169}$ The Court clearly finds preemptive conflict less objectionable than implied-repeal conflict. What explains this different treatment?

There are a number of related differences between preemptive conflict and implied-repeal conflict as the doctrines are currently conceptualized. First, preemptive conflict does not directly implicate legal updating. Second, the resolution of any given preemptive conflict is mandated by the Supremacy Clause. Finally, the Court has developed a greater number of

164. Silkwood, 464 U.S. at 248.

165. Id.; see also Winfield, 244 U.S. at 155 (Brandeis, J., dissenting).

166. 417 U.S. 535 (1974). In cases such as Morton v. Mancari, the Court takes an expanded approach to interpretation of legislative purpose in order to describe a lack of conflict. In contrast, in its cases establishing and applying obstacle preemption doctrine, the Court adopts a generous approach to interpretation of federal legislative purpose in order to detect conflict and therefore preemption. Despite criticism of obstacle preemption, see, e.g., Nelson, supra note 59, at 276-90, the Supreme Court still frequently acknowledges the doctrine. See, e.g., Sprietsma v. Mercury Marine, 537 U.S. 51,64 (2002); Crosby v. Nat'l Foreign Trade Council, 530 U.S. 363, 373 (2000); see also Geier v. Am. Honda Motor Co., 529 U.S. 861, 908 n.22 (2000) (Stevens, J., dissenting) (acknowledging Nelson's critique of obstacle preemption).

167. Geier, 529 U.S. at 907 (Stevens, J., dissenting) (citing cases).

168. See, e.g., Davis, supra note 160 , at 968 (arguing that there is in fact a presumption in favor of preemption).

169. See, e.g., New York v. F.E.R.C., 535 U.S. 1, 17 (2002) (aeknowledging "presumption against pre-emption" but dismissing it as irrelevant to the case); Egelhoff v. Egelhoff ex rel. Breiner, 532 U.S. 141, 151 (2001) (acknowledging "presumption against pre-emption" but noting that it "can be overcome," and concluding that it had been overcome in the present case); Buckman Co. v. Plaintiffs' Legal Comm., 531 U.S. 341, 341 (2001) (concluding that "no presumption against pre-emption obtains in this case"); see also Geier, 529 U.S. at 905-10 (Stevens, J., dissenting) (criticizing majority for too readily finding the presumption against preemption overcome). 
doctrinal tools for analyzing federalism conflicts than for analyzing temporal conflicts. ${ }^{170}$

These differences suggest that interpretive discretion openly used to police the constitutional allocation of federal-state power may be within courts' institutional competence and constitutional mandate in a way that interpretive discretion used to update the statutory scheme is not. However, it is far from clear that the notion of implied repeal is not contemplated by the Constitution. ${ }^{171}$ Arguably, the prohibition on legislative entrenchment supposes that the Constitution endorses legislative updating of the statutory scheme. ${ }^{172}$ Under this view, judicial frustration of legislative attempts to update, if not unconstitutional, is nevertheless just as problematic as judicial frustration of congressional attempts to exercise legitimate federal legislative power. The differences between the presumption against preemption and the presumption against implied repeals thus do not sufficiently explain the Court's contrasting attitudes toward the two presumptions. Only an unexamined hostility to statutory updating or a stubborn refusal to address the question can explain the difference. Retheorizing the presumption against implied repeals is a first step toward providing courts with the tools they need to move beyond this position.

\section{B. Heightened Stare Decisis for Statutory Precedents}

As Part I.C described, legislative updating may occur through statutory interpretation as well as through legislative enactment. One result of this practice is another type of statutory conflict, in which a court must choose between prior judicial interpretations of a statute and its determination of the correct interpretation to give that same statute in a different case or context. Courts have also taken a relatively sophisticated approach to this type of conflict, which, unlike preemptive conflict, does have a temporal dimension. Examination of this approach also provides useful lessons for a new approach to the problem of implied repeal.

A long-standing principle of judicial decision directs courts to observe a particularly strict form of stare decisis with respect to statutory-

170. Note, for instance, that while the lcad and dissenting opinions in Branch $v$. Smith provide careful analysis of the policies underlying the potential commandcering problem in the case, thcy do not mention the policies underlying the presumption against implied repeals at all. See 529 U.S. 254, 279-80, 301-04 (2003).

171. See The Federalist No. 78, at 398 (Alexander Hamilton) (E.P. Dutton 1937) (describing the latcr-enacted-statute rule as "not derived from any positive law, but from the nature and reason of the thing"); Nelson, supra note 59, at 237-60 (arguing that the non obstante clause with which the Supremacy Clause concludes was inserted as a directive to those applying the Constitution to refrain from applying the presumption against implied repeals in conflicts between federal and state law).

172. See Eule, supra note 41 , at 394-405 (arguing that the Framers intended the Constitution to create a legislative body with a limited "temporal mandate"). 
interpretation precedents. ${ }^{173}$ An early rationale for the principle reasoned that, to the extent that judicial interpretations of statutes are coextensive with the statutes' meanings, a sudden change in the interpretations can create problems of notice or upset private expectations. ${ }^{174}$ More recent rationales have appealed to Congress's superior institutional competency for making policy judgments and corrections, as well as to principles of public rather than private reliance. ${ }^{175}$ Variants of this approach note that Supreme Court interpretations of key statutes become part of the collection of statutory "building block[s]" on which legislatures base subsequent enactments $^{176}$ and that congressional failure to enact legislation overriding a judicial interpretation signals legislative acquiescence in the court's interpretation. $^{177}$

These reliance rationales are somewhat problematic. While reliance on statutory-interpretation precedents does occur, it does not justify a distinction between the stare decisis value appropriate for statutoryinterpretation precedents and that appropriate for constitutional or common-law precedents, which also prompt reliance by individuals and government. ${ }^{178}$ Moreover, reliance on statutory-interpretation precedents does not always occur. Perhaps as a result of this problem of justification, the asserted uniform presumption of correctness for statutory precedents does not accurately reflect judicial practice. ${ }^{179}$ On one account, evasion of the

173. See, e.g., ESKRIDGE, JR. ET AL., supra note 7, at 610-16. The Supreme Court, in particular, has at least since the 1940 s repeatedly cited a "super-strong presumption against overruling statutory precedents." Id. at 610 .

174. See, e.g., Douglass v. County of Pike, 101 U.S. 677, 687 (1879) (“After a statute has been settled by judicial construction, the construction becomes . . . as much a part of the statute as the text itself, and a change of decision is ... the same in its effect on contracts as an amendment of the law by means of a legislative enactment.").

175. See ESKRIDGE, JR., supra note 11, at 253.

176. See, e.g., William N. Eskridge, Jr., Overruling Statutory Precedents, 76 GEo. L.J. 1361, 1386 (1988).

177. See, e.g., Lawrence C. Marshall, "Let Congress Do It": The Case for an Absolute Rule of Statutory Stare Decisis, $88 \mathrm{MicH}$. L. REv. 177, 184-96 (1989). Another rationale for the rule is the notion that judicial interpretations of statutes, by assertedly explicating statutes in conformity with the principle of legislative supremacy, present themselves as simply glosses on the statutory language, that is, as very little more than extensions of the statutes themselves. See, e.g., DickERSON, supra note 11, at 252; see also Boys Mkts., 1nc. v. Retail Clerks Union, 398 U.S. 235, 257-58 (1970) (Black, J., dissenting) ("When the law has been settled by an earlier case then any subsequent 'reinterpretation' of the statute is ... neither more nor less than an amendment: it is no different from a judicial alteration of language that Congress itself placed in the statute.").

178. See Eskridge, Jr., supra note 176, at 1402. Also, the argument based on the relative institutional competence of courts and legislatures-which posits that courts should interfere in the process of lawmaking no more than necessary-is hard to square with the premise that courts are in effect amending statutes when they interpret them. See, e.g., Marshall, supra note 177, at 200-08. But see Eskridge, supra note 176, at 1397-1400 (noting that this "formalist 'judicial legislation' argument has never been accepted by a majority of the Court as a justification for the super-strong presumption").

179. In the years between 1961 and 1987, despite frequent invocation of the presumption, the Supreme Court overruled statutory precedents in more than eighty cases. Eskridge, Jr., supra note 176, Apps. A, B, \& C, at 1427-43. 
presumption occurs mainly through three doctrinal exceptions. The Court is willing to overrule statutory-interpretation precedents that did not result from adequate deliberation, as when such earlier interpretations occurred in dicta. ${ }^{180}$ The Court will also more readily overrule precedent involving the interpretation of statutes with constitutional or common-law dimensions, such as 42 U.S.C. $§ 1983 .{ }^{181}$ Finally, the Court may be willing to overrule precedent that has drawn criticism and has not prompted reliance. ${ }^{182}$

Although the presumption of correctness for statutory-interpretation precedents and the presumption against implied repeals both represent policies of hostility to statutory updating, the Court's willingness, in certain circumstances, to overrule statutory precedents differs from its current approach to the presumption against implied repeals. ${ }^{183}$ This difference may be due to the different ways the Court perceives the nature of the statutory updating in each type of statutory conflict. In overriding conflicting interpretive precedent, the Court is revisiting its own conclusions; in finding an implied repeal, the Court is drawing a conclusion about the meaning of legal commands that it did not originate. Yet this apparent distinction does not support a fundamentally different approach to the two types of conflict. At bottom, a conclusion of implied repeal is a matter of statutory interpretation, not a legislative act. ${ }^{184}$ Just as a legislature can correct any erroneous judicial reinterpretations of statutes that result from a court's overruling of its own statutory precedent, the legislature can correct erroneous conclusions of implied repeal by restoring the provisions found to have been repealed. Although it is clearly undesirable for a court to place a legislature in the position of having to take such a step, there is no principled reason to find this result more undesirable in the one situation than in the other. In the context of statutory-interpretation precedent, courts have developed doctrinal tools for ensuring that this result occurs rarely. ${ }^{185}$ There is no reason that they cannot do the same in the context of implied repeals. The next Part of this Comment, building on this parallel between the presumption of correctness for statutory precedents and the presumption against implied repeals, sketches some suggestions for a practical solution to the problem.

180. Id. at $1369-76$.

181. Id. at $1376-81$.

182. Id. at $1382-84$.

183. See supra note 118.

184. See discussion supra note 51.

185. See supra notes $180-83$ and accompanying text. 


\section{IV}

\section{Retheorizing the Presumption Against Implied Repeals}

\section{A. Alternative Rationales for the Presumption}

Throughout the long life of the presumption against implied repeals, the justifications offered for it have remained remarkably consistent. Coke justified the presumption on the basis of deference to legislative wisdom and supremacy. ${ }^{186} \mathrm{His}$ rationale was only slightly modified by nineteenthcentury treatise writers who justified the presumption by reference to the notion that legislatures would not and could not intend to contradict themselves. ${ }^{187}$ Courts using the presumption in the nineteenth and twentieth centuries remained tethered to narrow notions regarding unitary legislative intent, even after developing the comprehensive-revision rationale for implied repeal. ${ }^{188}$ The Supreme Court's recent simplified use of the presumption reflects an even narrower adherence to a constrained view of fixed and persistent institutional legislative will that the Court has never attempted to justify. ${ }^{189}$

Still, the presumption's encouragement of vertical coherence and judicial restraint surely reflects policies worth promoting. ${ }^{190}$ Replacing the flawed and theoretically impoverished existing justifications for the presumption with a new rationale can serve the double purpose of reestablishing a need for the presumption in some form and providing a systematic basis for determining when the presumption should be overcome. This Part examines alternative rationales for the presumption in order to determine a new set of justifications, which may serve as the basis for more nuanced doctrinal recommendations.

The most obvious alternative rationale is the formalist and institutional argument that the presumption, like other guidelines of statutory construction, is desirable because its consistent use will promote regularity of interpretive outcomes, clearer legislating, ${ }^{191}$ and therefore legal coherence. ${ }^{192}$ Under this view, the presumption is valuable primarily as a way of

186. Dr. Foster's Case, 77 Eng. Rep. 1222, 1232 (K.B. 1614).

187. See, e.g., MAXWELL, supra note 56, at 133-34; SEDGWICK, supra note 56, at 126-27.

188. See, e.g., Petri v. F.E. Creelman Lumber Co., 199 U.S. 487, 497 (1905); Cope v. Cope, 137 U.S. 682, 688 (1891); Murdock v. City of Memphis, 87 U.S. 590, 617 (1874); United States v. Jonas, 86 U.S. 598, 603 (1873); see also supra note 78.

189. See Eule, supra note 41.

190. See Shapiro, supra note 21.

191. See EsKRIDGE, JR., supra note 11, at 277 (quoting Finley v. United States, 490 U.S. 545, 556 (1989) (Scalia, J.)).

192. See id, at $239-40$. In 1985 , then Judge Scalia advanced a rationale for the presumption building on these premises:

It will not do to give this principle of statutory interpretation mere lip service and vacillating practical application. A steady adherence to it is important, primarily to facilitate not the task of judging but the task of legislating. It is one of the fundamental ground rules under which laws are framed. Without it, determining the effect of a bill upon the body of preexisting law would be inordinately difficult, and the legislative process would become distorted by a sort 
sending consistent signals to the legislature regarding the way in which statutes will be interpreted. But this rationale, without more, is selfdefeating. Unless courts expressly transform the presumption into a more nuanced interpretive tool, this rationale can only permit consistent use of a highly strengthened, virtually irrebuttable presumption. ${ }^{193}$ With this use of the canon, courts would ensure the clarity of their message to the legislature, but this message would at least sometimes necessarily misrepresent the actual fate of statutes at the hands of the judiciary. Consistent application of an irrebuttable presumption requires judicial reconciliation of statutes at all costs; this reconciliation will occasionally result in judicial updating of statutes, as it did in Argentine Republic v. Amerada Hess Shipping Corp. ${ }^{194}$ and Branch v. Smith. ${ }^{195}$ Such updating would be contrary to the message that use of a strict presumption would purport to send to the legislature. Moreover, the required judicial reconciliation of statutes will often be controlled not by consideration for the overall coherence of the statutory scheme but by the immediate necessity for demonstrating a lack of repugnance between two statutes. ${ }^{196}$ These problems suggest that the signaling rationale is unsatisfactory as a justification for the presumption against implied repeals in its current, oversimplified form. They also suggest the need for safeguards of candor and consistency in any proposed new rationale.

Even if the presumption cannot function to send reliable signals to the legislature, it might be valuable as a signaling device in another way. To the extent that the institutional role of courts is properly a conservative one, the anti-updating bias expressed by the presumption can function as a reminder to courts of that role and as a public statement by courts that they are cognizant of that role. ${ }^{197}$ Taken to its extreme, this view of courts as the inhibitors of legal change would seem to require use of the presumption as Justice O'Connor suggests applying it in Branch v. Smith-as an obstacle

of blind gamesmanship, in which Members of Congress vote for or against a particular measure according to their varying estimations of whether its implications will be held to suspend the effects of an earlier law that they favor or oppose.

United States v. Hansen, 772 F.2d 940, 944 (D.C. Cir. 1985). But see SCAL1A, supra note 11, at 28 ("To the honest textualist, all of these preferential rules and presumptions are a lot of trouble.").

193. The message sent by a consistently used presumption in favor of implied repeals would fail to send the legislature determinate information about the likely effects of any given law. The presumption against implied repeals signals that new statutes will not be understood to affect the meaning of old ones; a presumption in favor of implied repeals would signal that new statutes are likely to affect the meaning of old ones, without specifying the shape such effects would take.

194. 488 U.S. 428 (1989).

195. 538 U.S. 254 (2003).

196. Considerations of judieial economy make this result more likely. Just as the legislature cannot be expected to "comb[] the United States Code for possible inconsistencies with [every] new statute," Posner, supra note 8 , at 812 , courts should not be expected to ensure that their reconciliations themselves avoid all possible inconsistencies with the rest of the statutory scheme.

197. See Shapiro, supra note 21, at 941-50 (prescnting a normative defense of the proposition that the role of the judiciary should be essentially conservative). 
not only to judicial updating but also to legislative updating. ${ }^{198}$ Such an application is probably unpalatable to most courts, and with good reason. ${ }^{199}$ Yet the presumption need not become or remain overly rigid to function as a reminder or public statement of an anti-updating bias. As an initial step in a court's analysis of conflicting statutes, a rebuttable presumption might serve both functions while remaining sensitive to meaningful differences between various instances of statutory conflict.

These signaling rationales, together with the discussion of the stare decisis value of statutory-interpretation precedents in Part III.B, also suggest another defensible rationale. Both strains of the signaling rationale are based partly on notions of public reliance: legislatures rely on the fact that the existing framework of the law, against which they legislate, will remain in place through and after their legislative acts. ${ }^{200}$ But to the extent that reliance-both public and private-can justify the presumption against implied repeals, it justifies the presumption only as to those parts of the statutory scheme on which reliance has occurred or will be upset by unannounced alteration. It cannot justify use of the presumption to preserve those parts of the scheme on which it is highly unlikely that reliance has occurred or will be disturbed. ${ }^{201}$ Like the signaling rationales discussed above, a reliance rationale cannot justify a strict, unyielding presumption. But all these rationales strongly support a clearly articulated, more nuanced approach to the presumption. Parts IV.B and IV.C propose such an approach.

\section{B. The Shape of a New Presumption}

Given the analysis above, the presumption should be applied more selectively. Courts confronted with potentially conflicting statutes should always invoke the presumption but should calibrate the force to be given it through careful assessment of the likely degree of public and private reliance on the older of the potentially conflicting statutes. By turning the presumption into a guideline allowing judicially overseen updating of the

198. 538 U.S. at 297 (O’Connor, J., dissenting).

199. See supra notes 151-53 and accompanying text.

200. As Judge Posner has pointed out, taken to its logical extreme, this notion is equivalent to an empirically erroneous assumption of legislative omniscience. See supra notes $151-53$ and accompanying text. However, the notion need not necessarily be taken to this extreme. To the extent that awareness can bc imputed to a legislative body, it is possible to impute awareness of part of the existing statutory scheme to an enacting legislature without imputing omniscience, or awareness of the entirc statutory scheme, to that legislature. Such an imputation, unlike an imputation of legislative omniscience, is likely to be empirically supportable, for instance, by reference to the legislative history of the new enactment. Moreover, even if this assumption is not empirically supportable, it may be normatively desirable. See, e.g., HART \& SACKs, supra note 14, at 1374-80.

201. The public reliance to which then Judgc Scalia appealed in his formalist defense of the presumption, see supra note 192, suggests only a limited reliance on those parts of the statutory scheme that are fundamental "building blocks" of large parts of the scheme, see Eskridge, Jr., supra note 176, at 1386 , closely related in substance to the new enactment, or recently updated. 
statutory scheme in certain areas while warning against it in others, this approach would acknowledge the need to preserve vertical legal coherence-the great benefit of the presumption in its current form-while avoiding most of the presumption's current problems. ${ }^{202}$

Under this approach, courts should understand the presumption against implied repeals to be of varying weight, depending on consideration of two principal factors. One factor should be the nature of the older statute at issue. If public reliance on the older statute seems low because the social, economic, or legal conditions against which the original act was passed no longer obtain; because the scope of the older statute is relatively circumscribed; because the older statute is not arguably foundational; or because the older statute has not recently been enforced, amended, or discussed, the presumption should apply in a weaker form. ${ }^{203}$ If a conclusion of implied repeal would not upset private reliance on the older statute, the presumption should be weaker still. If, on the other hand, public reliance on the older statute seems high, if the older statute has been widely criticized yet not repealed, ${ }^{204}$ if the circumstances against which the statute was passed remain largely unchanged, or if congressional correction of any judicial misinterpretation of implied repeal would be difficult because the statute is primarily public-regarding, ${ }^{205}$ the presumption should remain quite strong. ${ }^{206}$

202. This approach would avoid the potential for irregular judicial updating and strained construction lurking in a too-rigid application of the presumption, because it would not force courts to reconcile statutes at any cost. It would avoid the empirical error of imputing omniscience to the legislature, as well as the error of refusing to acknowledge that legislatures might sometimes desire their enactments to have peripheral and unanticipated updating cffects elsewhere in the statutory scheme-or alternativcly that such peripheral effects might bc desirable, in the interest of maintaining the ovcrall horizontal coherence of the statutory scheme presumably also intended by the legislature. Finally, by explicitly allowing for statutory updating through implied repeals of limited scope, it would embrace a conception of temporally limited legislative will, resolving the dilemma described above in Part 1.C.

203. See discussion of the doctrincs developed for overcoming the prcsumption of correctness for statutory precedents, supra Part ll1.B.

204. Criticism of an older statute may already be a factor on which courts rely, but they do not usually do so openly. See SINGER, supra note 1, $\S 23: 10$, at 493 ("When there is widespread dissatisfaction with a rulc of law which continues in effect through the force of precedent and legislative inertia, ... thc courts may appear to favor implied repeal as a source of support for change helping to relicve the courts from full responsibility for making changes by judicial legislation.").

205. See, e.g., EsKRIDGE, JR. ET AL., supra note 7, at 784-85 (discussing proposals for interpretive approaches to public-regarding statutes).

206. This scheme for calibrating the strength of the presumption might appear to require new kinds of analysis, but courts routinely undertake similar assessments in other areas. See Eskridge, Jr., supra note 176, at 1386-91. The proposed scheme might also neccssitate a different use of legislative history than is currently practiced-instead of looking at legislative history to ascertain a legislature's intent or purpose in enacting a statute, a court would examine legislativc history to corroborate the court's analysis regarding the relationship between the older and newer potentially conflicting statutes. For a similar proposal, in a different context, see Bennett, supra note 53, at 7-9 (proposing use of legislative history in the service of a rehabilitated intentionalist approach to statutory interpretation). Mention of the relationship of the older statute to the newer one in the legislative history, for instance, 
A court can further refine its preliminary determination of the appropriate relative strength of the presumption by looking at the structural relationships between the older and newer statutes, relying where appropriate on the sub-rules regarding implied repeal that have long crowded treatises much more than case law. Some of these sub-rules reflect considerations similar to those outlined above. For example, the leading American statutory interpretation treatise notes that the "presumption is said to have special application to important public statutes of long standing." ${ }^{207}$ Other sub-rules recall a Coke-like logical analysis: "Where [a] later special or local statute is not irreconcilable with the general [earlier] statute, ... the general statute will not be repealed." ${ }^{208}$ Both substantive and formal subrules, which currently exist as a collection of isolated maxims, would gain coherence from being applied against the backdrop described above. Moreover, in accordance with this backdrop, courts could develop additional sub-rules.

Finally, after assessing the appropriate strength of the presumption, the court could move on to reconciling the statutes. If the presumption were very strong, current practice would obtain; the interpreting court would be free to reconcile the statutes using all available tools of statutory construction, even to the extent of imposing implausible meanings on the statutes or updating them. Such free-wheeling updating, if it occurred, would no longer be fundamentally inconsistent with an intentionalist rationale for the presumption. If the presumption had turned out to be weaker in the case of the statutes before the court, the court would need to be more circumspect in its attempt to reconcile the statutes discursively.

The proposed approach would replace the existing single-step approach to cases involving conflicting statutes with a two-step approach. Currently, some courts seem simply to apply a presumption of unvarying weight and attempt to reconcile the statutes, allowing the later statute to control only if reconciliation is impossible. This approach makes implied repeal extremely unlikely, and under this approach, the court's skill at reconciliation inappropriately carries the entire weight of the argument for or against iinplied repeal. The proposed approach, in contrast, would first require that the court analyze how much weight to give the presumption. Only after this analysis had been performed could an attempt to reconcile the statutes occur. This approach would force a court to present not one but

could lend weight to a conclusion of public reliance and to a strengthened presumption against implied repeals. On the other hand, undebated proposals that the earlier statute be expressly repealed might lend support to a weakened version of the presumption. See discussion infra Part IV.C. An initial search of the legislative history for this type of information could be performed fairly mechanically and would likely be far less time-consuming than combing legislative history for indications of legislators' intentions.

207. SINGER, supra note $1, \S 23: 10$, at $488-89$.

208. Id. $§ 23: 16$, at 520 . 
two justifications for any reconciliation of the statutes-not only a demonstration of the possibility of reconciliation, but also an analysis of how far that reconciliation might permissibly go, in the form of a preliminary analytic determination of the weight to be given the presumption. ${ }^{209}$

\section{Applying the New Presumption}

The proposed approach would not only promote a more forthright and sensitive analysis of statutory conflict, but also allow courts to reach defensible results through a series of relatively simple determinations. A comparison of how the proposed approach would function differently if applied to the conflicts at issue in Morton v. Mancari and in Branch v. Smith will confirm its utility.

In Morton $v$. Mancari, under the proposed approach, the Court would first have looked at the nature of the Indian Reorganization Act (IRA). This statute was forty years old at the time, but as its name suggests, it was a comprehensive attempt to "revolutioniz[e] Indian policy."210 In other words, it was a self-consciously foundational statute ${ }^{211}$ that embodied a complex policy scheme. Moreover, the IRA was a public-regarding statute that had been difficult to pass initially. ${ }^{212}$ Congressional resurrection of one of its provisions in the event of a finding of implied repcal would therefore be unlikely. Also, as the Court's purposive reconciliation of the statutes in Morton $v$. Mancari indicated, the conditions underlying and motivating the initial passage of the IRA had not disappeared by the time the EEOA was enacted. ${ }^{213}$ These considerations would support application of a stronger form of the presumption against implied repeals. The structural relationship between the two statutes, while more equivocal, ${ }^{214}$ would be a secondary consideration under the proposed approach. Application of a moderately strong presumption would allow a mild amount of judicial

209. Arguably, such an approach would require expenditure of additional judicial resources in a more complex analysis. However, it seems likely that the gains this approach would bring would outweigh any potential losses in judicial cconomy. The proposcd approach, if widely accepted, would make less likely the kind of fractured opinion exemplified by Branch v. Smith, 538 U.S. 254 (2003), and resulting from the current lack of consensus on the justifications for the presumption. Moreover, the proposed approach would send clcarer and more accurate messages to the legislature about how to draft statutes to avoid unintendcd implied repeals. See supra Part IV.A. This would reduee the necd for legislative correction of judicial mistakes.

210. Francis Paul Prucha, The Great Father: The United States Government and the AMERICAN INDIANS 321 (abridged ed. 1986). For Prucha's discussion of the drafting and passage of this act, see $i d$. at $321-25$.

211. See id. at 326-36 (describing the IRA as "thc heart of New Deal Indian reform").

212. Id. at 321-23.

213. 417 U.S. 535, 541-47 (1974)

214. The EEOA was also a foundational statute and an attcmpt to legislate comprehcnsively in a particular area, so the comprehensive-revision rationale for implied repeal might support a weakened prcsumption in this case. Also, the expressio unius canon (according to which unenumerated exceptions should not be read into the act) would arguably support a conclusion of implied repeal in this case. 
creativity in reconciling the statutes. As the Court's reasoning in Morton $v$. Mancari shows, the two statutes could be reconciled without significant interpretive gymnastics or ambiguous results. Under the Court's simple analysis, the different purposes of the two statutory schemes at issue meant that both could function simultaneously within a coherent statutory scheme. From a more textualist perspective, the Court's reconciliation disrupted the later statute's scheme only minimally, by reading an isolated additional exception into the EEOA, and sent a clear signal to Congress about the action it would need to take to correct any judicial mistake. This analysis illustrates that the Court would have reached the same conclusion in Morton v. Mancari under the proposed approach.

Application of the proposed approach to the statutory conflict at issue in Branch $v$. Smith, in contrast, would support only a rather weak presumption against implied repeals, as Justice Stevens concluded in his concurring opinion. ${ }^{215}$ The older statute in Branch $v$. Smith was sixty years old, but, as the plurality recognized, it was the sole remnant of a statutory scheme that had otherwise been almost completely invalidated by intervening constitutional decisions. ${ }^{216}$ The older statute was also a highly specific directive pertaining to a particular reapportionment circumstance. For both of these reasons, it could not plausibly be described as a foundational enactment. ${ }^{217}$ The legislative history of the later enactment also suggests that Congress did not rely on the continuing validity of this older statute when enacting the newer one. ${ }^{218}$ Consideration of the structural relationship between the statutes further supports only a relatively weak presumption against implied repeals: provided both statutes are interpreted to authorize redistricting by the same types of government bodies, the statutes appear to issue contradictory commands to those bodies. ${ }^{219}$ Under this analysis, only a minimally creative reconciliation of the statutes is defensible. Given the repugnancy between the statutes, no such reconciliation seems possible. ${ }^{220}$

215. 538 U.S. 254, 285 (2003) (Stevens, J., concurring in the judgment).

216. Id. at 273 .

217. Section $2 \mathrm{a}(\mathrm{c})(5)$ applied only when the number of representatives allocated to a state after reapportionment was less than the preexisting number of districts. In the context of the other provisions of $\S 2 \mathrm{a}(\mathrm{c})$, the directive of $\S 2 \mathrm{a}(\mathrm{c})(5)$ was arguably part of a statutory scheme expressing a coherent policy choice. But given the questionable constitutionality of those other provisions, $\S 2 \mathrm{a}(\mathrm{c})(5)$ became an anomalous requirement of at-large elections in a single type of circumstance only.

218. See 538 U.S. at 287-88 \& n.4, 289-90 (Stevens, J., concurring in the judgment) (describing that previous versions of the bill that became $\S 2 \mathrm{c}$ included provisions expressly repealing $\S 2 \mathrm{a}(\mathrm{c})(5))$. Although the later statute, as passed, did not expressly repeal the earlier one, the presence of such a provision in earlier versions of the bill did not engender any debate; it was other controversial provisions in the earlier bills that seem to have prevented their passage. Id.

219. This analysis does not address the distinct interpretive question of the correctness of the majority's conclusion that $\$ 2 \mathrm{c}$ authorized federal judicial redistricting.

220. Justice Scalia could only reconcile the statutes by reading into the earlier statute a temporal restriction absent from its language, see 538 U.S. at 275 , and by choosing to ignore the coherence problems generated by preserving the anomalous $\S 2 \mathrm{a}(\mathrm{c})(5)$ as the only remnant of an otherwise 
Under the proposed analysis, then, as Justice Stevens argued, the Court should have concluded that the later-enacted statute had impliedly repealed the earlier one in this case.

The suggested conclusion in Branch v. Smith, like the interpretive reconciliation the Court performed in Morton $v$. Mancari, would also send clear signals to the legislature. The proposed conclusion would let Congress know that if it wanted $\S 2 \mathrm{a}(\mathrm{c})(5)$ to survive despite its apparent incompatibility with $\S 2 \mathrm{c}$, it need only reenact the earlier provision. Such a shifting of responsibility to the legislature would be no more onerous than the corresponding shifting involved in potentially requiring Congress to reenact a clarified version of the earlier provision after the Court had altered its meaning through strained interpretive reconciliation in the service of an irrebuttable presumption against implied repeals. Moreover, the shifting of responsibility impelled by the proposed conclusion in Branch $v$. Smith would be more forthrightly consistent with the principle of legislative supremacy than is the ostensibly deferential but actually aggressive textual reconciliation of conflicting statutes that Justice Scalia performed. More generally, the proposed result in Branch $v$. Smith would send the signal that under certain circumstances, courts will indeed hold new statutes to have repealed older ones by implication. The proposed approach would therefore remind legislators of the need for circumspection in drafting laws affecting subject areas already covered by older statutes, to the extent that those legislators wish to retain control over the meaning of their legislative acts. This result, too, both respects and furthers legislative supremacy by reminding legislators of their responsibility for legislative meaning.

\section{Conclusion}

The presumption against implied repeals needs reconsideration. The presumption and its counterpart, the later-enacted-statute rule, purport to guide courts in situations of potential statutory conflict. As currently used by courts, however, these guidelines reflect incoherent and unexamined assumptions about the nature of statutory updating and the appropriate degree of judicial involvement in this enterprise. Even though the original justifications for the presumption against implied repeals are no longer universally accepted, no comprehensive new justification has been offered for its use. Undertheorization of the presumption has led to its too-rigid application, so that some courts seem to feel pressure to reconcile conflicting statutes at any cost. This makes the courts' interpretive conclusions unpredictable and undermines the principle of legislative supremacy.

arguably invalid scheme, see id. at 273. In her dissent, Justice O'Connor repeatedly pointed out the inconsistencies between this reconciliation and Justice Scalia's statements on statutory interpretation elsewhere. Id. at 298-299, 304 (O'Connor, J., dissenting). See also supra note 144. 
Nevertheless, the presumption reflects valid concerns and can remain a valuable tool for courts considering two conflicting statutes. The presumption should be reestablished as a more flexible and more principled guideline, based on notions of signaling and reliance. This retheorization of the presumption, together with the type of statutory analysis that logically follows from it, better furthers the goal of legislative supremacy by promoting more transparent reasoning by courts attempting to reconcile conflicting statutes. The proposed approach also provides courts with a versatile mechanism for maximizing both the continuity and the coherence of the statutory scheme.

\section{APPENDIX:}

SuPreme Court Cases Addressing IMPLied RePEALS, 1809-2003

The following cases, listed in chronological order, were collected through Boolean searches for United States Supreme Court cases in online databases. The searches retrieved cases in which the roots "impl-" and "repeal-" appeared within the same paragraph. I discarded early cases in which arguments about implied repeal were made by the parties but not addressed by the Court in its opinion, some cases in which the Court summarily dismissed an argument that an implied repeal had occurred in dicta by finding the doctrine of implied repeals inapplicable or by finding an express repeal, and cases in which the term "implied repeal" was used to rcfer to statutory alterations of common law. I have included dissenting opinions mentioning implied repeals or the presumption against implied repeals in cases in which the majority opinion does not include such a mention, and I have noted whether or not each opinion notes, concludes, or argues that an implied repeal had occurred ("yes" means that the Court or Justice did conclude this, "no" that it found no implied repeal).

Yeaton v. Bank of Alexandria, 9 U.S. (5 Cranch) 49 (1809) (Johnson, J., dissenting in part) (no).

Harford v. United States, 12 U.S. (8 Cranch) 109 (1814) (no).

Mutual Assurance Soc'y v. Watts' Ex'r, 14 U.S. (1 Wheat.) 279 (1916) (no).

Rutherford v. Greene's Heirs, 15 U.S. (2 Wheat.) 196 (1817) (no).

Chirac v. Chirac's Lessee, 15 U.S. (2 Wheat.) 259 (1817) (no).

The Star, 16 U.S. (3 Wheat.) 78 (1818) (no).

The Estrella, 17 U.S. (4 Wheat.) 298 (1819) (no).

The Margaret, 22 U.S. (9 Wheat.) 421 (1824) (no).

Soc'y for Propagation of Gospel in Foreign Parts v. Town of Pawlet, 29 U.S. (4 Pet.) 480 (1830) (yes).

Wilcox v. Jackson ex dem. McConnel, 38 U.S. (13 Pet.) 498 (1839) (no).

Lattimer's Lessee v. Poteet, 39 U.S. (16 Pet.) 4 (1840) (no).

Wood v. United States, 41 U.S. (16 Pet.) 342 (1842) (no). 
Aldridge v. Williams, 44 U.S. (3 How.) 9 (1845) (no).

United States v. Gear, 44 U.S. (3 How.) 120 (1845) (no).

Daviess v. Fairbairn, 44 U.S. (3 How.) 636 (1845) (no).

Beals v. Hale, 45 U.S. (4 How.) 37 (1846) (no).

Norris v. Crocker, 54 U.S. (13 How.) 429 (1851) (yes).

Lawrence v. Caswell, 54 U.S. (13 How.) 488 (1851) (no).

Doolittle's Lessee v. Bryan, 55 U.S. (14 How.) 563 (1852) (no).

Stuart v. Maxwell, 57 U.S. (16 How.) 150 (1853) (no).

United States v. Sixty-Seven Packages of Dry Goods, 58 U.S. (17 How.) 85 (1854) (yes).

United States v. One Package of Merch., 58 U.S. (1 7 How.) 98 (1854) (yes).

United States v. One Case of Clocks, 58 U.S. (17 How.) 99 (1854) (yes).

United States v. Ritchie, 58 U.S. (17 How.) 525 (1854) (yes).

Converse v. United States, 62 U.S. (21 How.) 463 (1858) (Campbell, J., dissenting) (no).

United States v. Walker, 63 U.S. (22 How.) 299 (1859) (no).

Zabriskie v. Cleveland, Columbus \& Cincinnati R.R. Co., 64 U.S. (23 How.) 381 (1859) (no).

McCool v. Smith, 66 U.S. (1 Black) 459 (1861) (no).

United States v. Vallejo, 66 U.S. (I Black) 541 (1861) (yes).

Godfrey v. Eames, 68 U.S. (2 Wall.) 317 (1863) (yes).

Pac. Mail S.S. Co. v. Joliffe, 69 U.S. (2 Wall.) 450 (1864) (no).

The Reform, 70 U.S. (3 Wall.) 617 (1865) (no).

United States v. Scott, 70 U.S. (3 Wall.) 642 (1865) (no).

City of Galena v. Amy, 72 U.S. (5 Wall.) 705 (1866) (no).

Furman v. Nichol, 75 U.S. (8 Wall.) 44 (1868) (no).

Ex parte Yerger, 75 U.S. (8 Wall.) 85 (1868) (no).

United States v. Tynen, 78 U.S. (11 Wall.) 88 (1870) (yes).

In re Distilled Spirits, 78 U.S. (11 Wall.) 356 (1870) (no).

The Cherokee Tobacco, 78 U.S. (11 Wall.) 616 (1870) (Bradley, J., dissenting) (no).

United States v. Lynde, 78 U.S. (11 Wall.) 632 (1870) (yes).

In re Henderson's Tobacco, 78 U.S. (11 Wall.) 652 (1870) (no).

Stockwell v. United States, 80 U.S. (13 Wall.) 531 (1871) (no).

Osborn v. Nicholson, 80 U.S. (13 Wall.) 654 (1871) (no).

South Carolina v. Stoll, 84 U.S. (17 Wall.) 425 (1873) (no).

N.J. Steamboat Co. v. Collector, 85 U.S. (18 Wall.) 478 (1873) (yes).

W. Union Tel. Co. v. Eyser, 86 U.S. (19 Wall.) 419 (1873) (Clifford, J., dissenting) (no).

United States v. Jonas, 86 U.S. (19 Wall.) 598 (1873) (yes).

In re Twenty Per Cent. Cases, 87 U.S. (20 Wall.) 179 (1873) (no).

Murdock v. City of Memphis, 87 U.S. (20 Wall.) 590 (1874) (yes).

Bailey v. Magwire, 89 U.S. (22 Wall.) 215 (1874) (no). 
Fox v. Seal, 89 U.S. 424 (22 Wall.) (1874) (no).

Smythe v. Fiske, 90 U.S. (23 Wall.) 374 (1874) (no).

Barney v. Watson, 92 U.S. 449 (1875) (yes).

In re Hot Springs Cases, 92 U.S. 698 (1875) (no).

Bd. of Sup'rs v. Lackawanna Iron \& Coal Co., 93 U.S. 619 (1876) (no).

Kibbe v. Ditto, 93 U.S. 674 (1876) (yes).

Fabbri v. Murphy, 95 U.S. 191 (1877) (no).

United States v. Gillis, 95 U.S. 407 (1877) (no).

Arthur v. Homer, 96 U.S. 137 (I877) (no).

Kohlsaat v. Murphy, 96 U.S. 153 (1877) (yes).

Welch v. Cook, 97 U.S. 541 (1878) (yes).

United States v. Claflin, 97 U.S. 546 (1878) (yes).

Barney v. Dolph, 97 U.S. 652 (1878) (yes).

United States v. Winchester, 99 U.S. 372 (1878) (no).

Block v. Bourbon County Comm'rs, 99 U.S. 686 (1878) (no).

Anthony v. Jasper County, 101 U.S. 693 (1879) (no).

Wright v. Nagle, 101 U.S. 791 (1879) (no).

Wilmot v. Mudge, 103 U.S. 217 (1880) (no).

Relfe v. Wilson, 26 L. Ed. 212 (1880) (no).

United States v. Taylor, 104 U.S. 216 (1881) (no).

Clay County v. Soc'y for Savings, 104 U.S. 579 (I 881 ) (no).

City of Louisiana v. Taylor, 105 U.S. 454 (1881) (no).

King v. Comell, 106 U.S. 395 (1882) (yes).

Town of Red Rock v. Henry, 106 U.S. 596 (1883) (no).

Russell v. Williams, 106 U.S. 623 (1882) (no).

Cook County Nat'l Bank v. United States, 107 U.S. 445 (1883) (yes).

Town of Pana v. Bowler, 107 U.S. 529 (1883) (yes).

City of Savannah v. Kelly, 108 U.S. 184 (1883) (no).

City of Savannah v. Martin, 108 U.S. 191 (1883) (no).

United States v. Fisher, 109 U.S. 143 (1883) (yes).

Arnson v. Murphy, 109 U.S. 238 (1883) (yes).

Ex parte Kan-gi-shun-ca, 109 U.S. 556 (1883) (no).

Chew Heong v. United States, 112 U.S. 536 (1884) (no).

Hess v. Reynolds, 113 U.S. 73 (1885) (no).

Union Pac. Ry. Co. v. Ryan, 113 U.S. 516 (1885) (yes).

Fussell v. Gregg, 113 U.S. 550 (1885) (no).

Saxonville Mills v. Russell, 116 U.S. 13 (1885) (no).

United States v. Mooney, 116 U.S. 104 (1885) (no).

Louisiana v. Police Jury, 116 U.S. 135 (1885) (yes).

United States v. Landram, 118 U.S. 81 (1886) (no).

United States v. Langston, 118 U.S. 389 (1886) (no).

United States v. Northway, 120 U.S. 327 (1887) (yes). 
Mathews v. United States, 123 U.S. 182 (1887) (yes).

Lovejoy v. United States, 128 U.S. 171 (1888) (no).

Traey v. Tuffly, 134 U.S. 206 (1890) (yes).

Eckloff v. District of Columbia, 135 U.S. 240 (1890) (yes).

Cope v. Cope, 137 U.S. 682 (1891) (no).

Fisk v. Henarie, 142 U.S. 459 (1892) (yes).

Louisville Water Co. v. Clark, 143 U.S. 1 (1892) (yes).

District of Columbia v. Hutton, 143 U.S. 18 (1892) (yes).

Lau Ow Bew v. United States, 144 U.S. 47 (1892) (no).

Smithmeyer v. United States, 147 U.S. 342 (1893) (no).

Smith v. Townsend, 148 U.S. 490 (1893) (no).

Lees v. United States, 150 U.S. 476 (1893) (no).

Belknap v. United States, 150 U.S. 588 (1893) (yes).

St. Clair v. United States, 154 U.S. 134 (1894) (no).

Mattox v. United States, 156 U.S. 237 (1895) (yes).

Frost v. Wenie, 157 U.S. 46 (1895) (no).

United States v. Union Pac. Ry. Co., 160 U.S. 1 (1895) (no).

United States v. Healey, 160 U.S. 136 (1895) (no).

United States v. New York, 160 U.S. 598 (1896) (no).

United States v. Rider, 163 U.S. 132 (1896) (yes).

United States v. Allen, 163 U.S. 499 (1896) (yes).

Ward v. Race Horse, 163 U.S. 504 (1896) (yes).

United States v. Hewecker, 164 U.S. 46 (1896) (yes).

Borrego v. Cunningham, 164 U.S. 612 (1896) (no).

United States v. Trans-Missouri Freight Ass'n, 166 U.S. 290 (1897) (no).

United States v. Greathouse, 166 U.S. 601 (1897) (no).

United States v. Reed, 167 U.S. 664 (1897) (no).

Henrietta Mining \& Milling Co. v. Gardner, 173 U.S. 123 (1899) (yes).

The Paquete Habana, 175 U.S. 677 (1900) (yes).

Hewitt v. Schultz, 180 U.S. 139 (1901) (Brewer, J., dissenting) (no).

Freeport Water Co. v. City of Freeport, 180 U.S. 587 (1901) (White, J., dissenting) (no).

De Lima v. Bidwell, 182 U.S. 1 (1901) (yes).

McChord v. Cincinnati, New Orleans \& Tex. Pac. Ry. Co., 183 U.S. 483 (1902) (no).

Louisville \& Nashville R.R. Co. v. Kentucky, 183 U.S. 503 (1902) (no).

Rodgers v. United States, 185 U.S. 83 (1902) (no).

United States v. Lee Yen Tai, 185 U.S. 213 (1902) (no).

Murphy v. Utter, 186 U.S. 95 (1902) (yes).

Bird v. United States, 187 U.S. 118 (1902) (no).

Ind. Mfg. Co. v. Koehne, 188 U.S. 681 (1903) (no).

Union Stcamboat Co. v. Erie \& W. Transp. Co., 189 U.S. 363 (1903) (no). 
Lowe v. United States, 194 U.S. 193 (1904) (yes).

Gibson v. United States, 194 U.S. 182 (1904) (yes).

Petri v. F.E. Creelman Lumber Co., 199 U.S. 487 (1905) (no).

Johnson v. Browne, 205 U.S. 309 (1907) (no).

Winters v. United States, 207 U.S. 564 (1908) (no).

Great N. Ry. Co. v. United States, 208 U.S. 452 (1908) (no).

Louisiana v. Garfield, 211 U.S. 70 (1908) (no).

Hertz v. Woodman, 218 U.S. 205 (1910) (no).

United States v. Morgan, 222 U.S. 274 (1911) (no).

United States v. Barnes, 222 U.S. 513 (1912) (no).

Ex parte United States, 226 U.S. 420 (1913) (no).

United States v. Wright, 229 U.S. 226 (1913) (no).

Donnelly v. United States, 228 U.S. 243 (1913) (yes).

Mitchell Coal \& Coke Co. v. Pa. R.R. Co., 230 U.S. 247 (1913) (no).

New York ex rel. Amoskeag Sav. Bank of Manchester, 231 U.S. 373 (1913) (yes).

Rainey v. W.R. Grace \& Co., 231 U.S. 703 (1914) (yes).

United States v. Vulte, 233 U.S. 509 (1914) (no).

Johnson v. Gearlds, 234 U.S. 422 (1914) (no).

Washington v. Miller, 235 U.S. 422 (1914) (no).

Joplin Mercantile Co. v. United States, 236 U.S. 531 (1915) (yes).

De Elzaburu v. Chaves, 239 U.S. 283 (1915) (no).

Inter-Island Steam Navigation Co. v. Byrne, 239 U.S. 459 (1915) (yes).

Northwestern Laundry v. City of Des Moines, 239 U.S. 486 (1916) (no).

United States v. Hemmer, 241 U.S. 379 (1916) (no).

Louisville Bridge Co. v. United States, 242 U.S. 409 (1917) (yes).

Lewis v. United States, 244 U.S. 134 (1917) (yes).

United States ex rel. Louisiana v. Boarman, 244 U.S. 397 (1917) (no).

Sears v. City of Akron, 246 U.S. 242 (1918) (no).

City of Mitchell v. Dakota Cent. Tel. Co., 246 U.S. 396 (1918) (yes).

J. Homer Fritch, Inc. v. United States, 248 U.S. 458 (1919) (no).

Hamilton v. Ky. Distilleries \& Warehouse Co., 251 U.S. 146 (1919) (no).

Shaffer v. Carter, 252 U.S. 37 (1920) (no).

Marshall v. New York, 254 U.S. 380 (1920) (no).

Duplex Printing Press Co. v. Deering, 254 U.S. 443 (1921) (no).

Vicksburg, Shreveport \& Pac. Ry. Co. v. Anderson-Tully Co., 256 U.S. 408 (1921) (no).

United States v. Yuginovich, 256 U.S. 450 (1921) (yes).

Grogan v. Hiram Walker \& Sons, 259 U.S. 80 (1922) (yes).

Takao Ozawa v. United States, 260 U.S. 178 (1922) (no).

Jay Burns Baking Co. v. Bryan, 264 U.S. 504 (1924) (yes).

Kennedy v. United States, 265 U.S. 344 (1924) (no).

In re E. River Towing Co., 266 U.S. 355 (1924) (no). 
United States v. Noce, 268 U.S. 613 (1925) (no).

United States v. Onc Ford Coupe Auto., 272 U.S. 321 (1926) (no).

United States v. Noveck, 273 U.S. 202 (1927) (no).

Maul v. United States, 274 U.S. 501 (1927) (no).

Graham v. Goodcell, 282 U.S. 409 (1931) (no).

Gen. Motors Acceptance Corp. v. United States, 286 U.S. 49 (1932) (no).

McCormick \& Co. v. Brown, 286 U.S. 131 (1932) (no).

United States v. Burroughs, 289 U.S. 159 (1933) (no).

Pigeon River Improvement Co. v. Charles W. Cox, Ltd., 291 U.S. 138 (1934) (no).

United States v. Jefferson Elec. Mfg. Co., 291 U.S. 386 (1934) (no).

Gay v. Ruff, 292 U.S. 25 (1934) (no).

Posadas v. Nat'l City Bank, 296 U.S. 497 (1936) (no).

Morf v. Bingaman, 298 U.S. 407 (1936) (no).

United States v. Jackson, 302 U.S. 628 (1938) (no).

United States v. Borden Co., 308 U.S. 188 (1939) (no).

W. India Oil Co. v. Domenech, 311 U.S. 20 (1940) (no).

United States v. Gilliland, 312 U.S. 86 (1941) (no).

United States v. Hutcheson, 312 U.S. 219 (1941) (Roberts, J., dissenting) (no).

Edwards v. United States, 312 U.S. 473 (1941) (no).

Benitez Sampayo v. Bank of Nova Scotia, 313 U.S. 270 (1941) (no).

United States v. Santa Fc Pac. R. Co., 314 U.S. 339 (1941) (no).

Cloverleaf Butter Co. v. Patterson, 315 U.S. 148 (1942) (Stone, J., dissenting) (no).

Penn Dairies v. Milk Control Comm'n, 318 U.S. 261 (1943) (no).

Ex parte Republic of Peru, 318 U.S. 578 (1943) (no).

Freeman v. Bee Mach. Co., 319 U.S. 448 (1943) (Frankfurter, J., dissenting) (no).

Georgia v. Pennsylvania R.R. Co., 324 U.S. 439 (1945) (no).

U.S. Alkali Export Ass'n v. U.S., 325 U.S. 196 (1945) (no).

Girouard v. United States, 328 U.S. 61 (1946) (Stone, J., dissenting) (no).

FTC v. A.P.W. Paper Co., 328 U.S. 193 (1946) (no).

Blumenthal v. United States, 332 U.S. 539 (1947) (no).

United States v. Line Material Co., 333 U.S. 287 (1948) (Burton, J., dissenting) (no).

Ex parte Collett, 337 U.S. 55 (1949) (no).

Kilpatrick v. Tex. \& Pac. Ry. Co., 337 U.S. 75 (1949) (no).

Youngstown Sheet \& Tube Co. v. Sawyer, 343 U.S. 579 (1952) (no).

Fed. Power Comm'n v. Idaho Power Co., 344 U.S. 17 (1952) (no).

United States v. Beacon Brass Co., 344 U.S. 43 (1952) (no).

De La Rama S.S. Co. v. U.S., 344 U.S. 386 (1953) (no).

District of Columbia v. John R. Thompson Co., 346 U.S. 100 (1953) (no).

Rosenberg v. United States, 346 U.S. 273 (1953) (no).

Braniff Airways v. Nebraska State Bd. of Equalization, 347 U.S. 590 (1954) (no). 
Norwood v. Kirkpatrick, 349 U.S. 29 (1955) (Clark, J., dissenting) (no).

Achilli v. United States, 353 U.S. 373 (1957) (yes).

Pan-Atlantic S.S. Corp. v. Atl. Coast Line R.R. Co., 353 U.S. 436 (1957) (Burton, $J$, dissenting) (no).

United States v. E.I. du Pont de Nemours \& Co., 353 U.S. 586 (1957) (Burton, J., dissenting) (no).

Pub. Utils. Comm'n v. United States, 355 U.S. 534 (I958) (Harlan, J., dissenting) (no).

Miner v. Atlass, 363 U.S. 641 (1960) (Brennan, J., dissenting) (yes).

Mich. Nat'l Bank v. Miehigan, 365 U.S. 467 (1961) (Whittaker, J., dissenting) (no).

Laurens Fed. Sav. \& Loan Ass'n v. S.C. Tax Comm'n, 365 U.S. 517 (1961) (no).

McGowan v. Maryland, 366 U.S. 420 (1961) (Frankfurter, J., separate opinion) (yes).

Sinclair Ref. Co. v. Atkinson, 370 U.S. 195 (1962) (no).

United States v. Wise, 370 U.S. 405 (1962) (no).

Pan Am. World Airways, Inc. v. United States, 371 U.S. 319 (1963) (Brennan, J., dissenting) (no).

Mercantile Nat'l Bank v. Langdeau, 371 U.S. 555 (1963) (no).

Bhd. of Locomotive Eng'rs v. Louisville \& Nashville R.R. Co., 373 U.S. 33 (1963) (Goldberg, J., dissenting) (no).

Silver v. N.Y. Stock Exch., 373 U.S. 341 (1963) (no).

United States v. Phila. Nat'1 Bank, 374 U.S. 321 (1963) (no).

United States v. Welden, 377 U.S. 95 (1964) (no).

Carnation Co. v. Pac. Westbound Conference, 383 U.S. 213 (1966) (no).

Amell v. United States, 384 U.S. 158 (1966) (no).

Fleischmann Distilling Corp. v. Maier Brewing Co., 386 U.S. 714 (1967) (Stewart, J., dissenting) (no).

Washington v. Texas, 388 U.S. 14 (1967) (yes).

Kaplan v. Lehman Bros., 389 U.S. 954 (1967) (Warren, J., dissenting) (no).

Menominee Tribe v. United States, 391 U.S. 404 (1968) (no).

Jones v. Alfred H. Mayer Co., 392 U.S. 409 (1968) (no).

United States v. Vuitch, 402 U.S. 62 (1971) (Harlan, J., dissenting) (no).

Lynch v. Household Fin. Corp., 405 U.S. 538 (I972) (no).

Hughes Tool Co. v. Trans World Airlines, Inc., 409 U.S. 363 (1973) (Burger, J., dissenting) (no).

Otter Tail Power Co. v. United States, 410 U.S. 366 (1973) (no).

Fed. Mar. Comm'n v. Seatrain Line, Inc., 411 U.S. 726 (1973) (no).

United States v. Students Challenging Regulatory Agency Procedures, 412 U.S. 669 (1973) (no)

Corning Glass Works v. Brennan, 417 U.S. 188 (1974) (yes).

Morton v. Mancari, 417 U.S. 535 (1974) (no).

Richardson v. Ramirez, 418 U.S. 24 (1974) (no). 
Blanchette v. Conn. Gen. Ins. Corps., 419 U.S. 102 (1974) (no).

Schlesinger v. Councilman, 420 U.S. 738 (1975) (no).

Aberdeen \& Rockfish R.R Co. v. Students Challenging Regulatory Agency Procedures, 422 U.S. 289 (1975) (no).

FAA v. Robertson, 422 U.S. 255 (1975) (no).

Gordon v. N.Y. Stock Exch., Inc., 422 U.S. 659 (1975) (yes).

Colo. River Water Conservation Dist. v. United States, 424 U.S. 800 (1976) (no).

United States v. United Cont'l Tuna Corp., 425 U.S. 164 (1976) (no).

Radzanower v. Touche Ross \& Co., 426 U.S. 148 (1976) (no).

Examining Bd. of Eng'rs, Architects \& Surveyors v. Flores de Otero, 426 U.S. 572 (1976) (no).

Flint Ridge Dev. Co. v. Scenic Rivers Ass'n, 426 U.S. 776 (1976) (no).

Runyon v. McCrary, 427 U.S. 160 (1976) (no).

Cantor v. Detroit Edison Co., 428 U.S. 579 (1976) (no).

City of Lafayette v. La. Power \& Light Co., 435 U.S. 389 (1978) (no).

Vt. Yankee Nuclear Power Corp. v. Natural Res. Def. Council, Inc., 435 U.S. 519 (1978) (no).

Tenn. Valley Auth. v. Hill, 437 U.S. 153 (1978) (no).

N.Y. Tel. Co. v. Dep't of Labor, 440 U.S. 519 (1979) (Powell, J., dissenting) (no).

United States v. Batchelder, 442 U.S. 114 (1979) (no).

Great Am. Fed. Sav. \& Loan Ass'n v. Novotny, 442 U.S. 366 (1979) (White, J., dissenting) (no).

Busic v. United States, 446 U.S. 398 (1980) (no).

Andrus v. Glover Constr. Co., 446 U.S. 608 (1980) (no).

Allen v. McCurry, 449 U.S. 90 (I980) (no).

United States v. Will, 449 U.S. 200 (1980) (yes).

Watt v. Alaska, 451 U.S. 259 (1981) (no).

St. Martin Evangelical Lutheran Church v. South Dakota, 451 U.S. 772 (1981) (no).

Washington County v. Gunther, 452 U.S. 161 (1981) (Rehnquist, J., dissenting) (no).

Nat'l Gerimedical Hosp. \& Gerontology Ctr. v. Blue Cross, 452 U.S. 378 (1981) (no).

Cmty. Communications Co., Inc. v. City of Boulder, 455 U.S. 40 (1982) (no).

Kaiser Steel Corp. v. Mullins, 455 U.S. 72 (1982) (no).

Weinberger v. Rossi, 456 U.S. 25 (1982) (no).

Kremer v. Chemical Constr. Corp., 456 U.S. 461 (1982) (no).

McCain v. Lybrand, 465 U.S. 236 (1984) (no).

Ruckelshaus v. Monsanto Co., 467 U.S. 986 (1984) (no).

Secs. Indus. Ass'n v. Bd. of Governors, 468 U.S. 137 (1984) (O'Connnor, J., dissenting) (no).

Fed. Election Comm'n v. Nat'l Conservative Political Action Comm., 470 U.S. 480 (1985) (White, J., dissenting) (no). 
Ball v. United States, 470 U.S. 856 (1985) (no).

S. Motor Carriers Rate Conference, Inc. v. United States, 471 U.S. 48 (1985) (Stevens, J., dissenting) (yes).

Northwest Wholesale Stationers, Inc. v. Pac. Stationery \& Printing Co., 472 U.S. 284 (1985) (no).

Parsons Steel, Inc. v. First Ala. Bank, 474 U.S. 518 (1986) (no).

Square D Co. v. Niagara Frontier Tariff Bureau, Inc., 476 U.S. 409 (1986) (no).

Randall v. Loftsgaarden, 478 U.S. 647 (1986) (no).

Kelly v. Robinson, 479 U.S. 36 (1986) (no).

Rodriguez v. United States, 480 U.S. 522 (1987) (no).

Traynor v. Turnage, 485 U.S. 535 (1988) (no).

Goodyear Atomic Corp. v. Miller, 486 U.S. 174 (1988) (no).

Argentine Republic v. Amerada Hess Shipping Corp., 488 U.S. 428 (1989) (no).

Cotton Petroleum Corp. v. New Mexico, 490 U.S. 163 (1989) (no).

W. Va. Univ. Hosps., Inc. v. Casey, 499 U.S. 83 (1991) (no).

Astoria Fed. Sav. \& Loan Ass'n v. Solimino, 501 U.S. 104 (1991) (no).

Wooddell v. Int'l Bhd. of Elec. Workers, Local 71, 502 U.S. 93 (1991) (no).

County of Yakima v. Yakima Indian Nation, 502 U.S. 251 (1992) (no).

FTC v. Ticor Title Ins. Co., 504 U.S. 621 (1992) (no).

Negonsott v. Samuels, 507 U.S. 99 (1993) (no).

Hagen v. Utah, 510 U.S. 399 (1994) (no).

United States v. Aguilar, 515 U.S. 593 (1995) (no).

Matsushita Elec. Indus. Co., Ltd. v. Epstein, 516 U.S. 367 (1996) (no).

Henderson v. United States, 517 U.S. 654 (1996) (Thomas, J., dissenting) (no).

Reno v. Am.-Arab Anti-Discrimination Comm., 525 U.S. 471 (1999) (Souter, J., dissenting) (no).

Minnesota v. Mille Lacs Band of Chippewa Indians, 526 U.S. 172 (1999) (no).

Dir. of Revenue v. CoBank ACB, 531 U.S. 316 (2001) (no).

Central Green Co. v. United States, 531 U.S. 425 (2001) (no).

J.E.M. AG Supply, Inc. v. Pioneer Hi-Bred Intern., Inc., 534 U.S. 124 (2001) (no).

United States v. Vonn, 535 U.S. 55 (2002) (no).

Branch v. Smith, 538 U.S. 254 (2003) (no).

Cook County v. United States ex rel. Chandler, 538 U.S. 119 (2003) (no). 